\section{(A) Check for updates}

Cite this: Polym. Chem., 2020, 11 6308

\title{
L- and rac-lactide polymerisation using scandium and aluminium permethylindenyl complexes $\uparrow$
}

\author{
Nichabhat Diteepeng, (D) Isobel A. P. Wilson, Jean-Charles Buffet, (D) \\ Zoë R. Turner (D) and Dermot O'Hare (D) *
}

\begin{abstract}
The synthesis and characterisation of constrained geometry scandium and aluminium permethylindenyl complexes ${ }^{\mathrm{Me} 2} \mathrm{SB}\left({ }^{\mathrm{R}} \mathrm{N}, I^{*}\right) \mathrm{ScCl}(\mathrm{THF})\left(\mathrm{R}={ }^{i} \mathrm{Pr}(\mathbf{1}),{ }^{n} \mathrm{Bu}(\mathbf{2})\right.$ and $\left.\mathrm{Ph}(\mathbf{3})\right),{ }^{\mathrm{Me} 2} \mathrm{SB}\left({ }^{i} \mathrm{Pr} N, I^{*}\right) \mathrm{Sc}\left(\mathrm{O}-2,6-{ }^{i} \mathrm{Pr}-\mathrm{C}_{6} \mathrm{H}_{3}\right)(\mathrm{THF})$ (4), ${ }^{\mathrm{Me} 2} \mathrm{SB}\left({ }^{\mathrm{P} r} \mathrm{~N}, \mathrm{I}^{*}\right) \mathrm{Sc}\left(\mathrm{O}-2,4-{ }^{t} \mathrm{Bu}-\mathrm{C}_{6} \mathrm{H}_{3}\right)(\mathrm{THF})(5),{ }^{\mathrm{Me} 2} \mathrm{SB}\left({ }^{n B u} \mathrm{~N}, \mathrm{I}^{*}\right) \mathrm{SC}\left(\mathrm{O}-2,6-{ }^{i} \mathrm{Pr}-\mathrm{C}_{6} \mathrm{H}_{3}\right)(\mathrm{THF})(6),{ }^{\mathrm{Me} 2} \mathrm{SB}\left({ }^{\mathrm{Ph}} \mathrm{N}, \mathrm{I}^{*}\right) \mathrm{SC}$ $\left(\mathrm{O}-2,6-{ }^{i} \mathrm{Pr}-\mathrm{C}_{6} \mathrm{H}_{3}\right)(\mathrm{THF}) \quad$ (7), ${ }^{\mathrm{Me} 2} \mathrm{SB}\left({ }^{t \mathrm{Bu}} \mathrm{N}, \mathrm{I}^{*}\right) \mathrm{AlCl}(\mathrm{THF}) \quad(8),{ }^{\mathrm{Me} 2} \mathrm{SB}\left({ }^{\mathrm{BBu}} \mathrm{N}, I^{*}\right) \mathrm{Al}\left(\mathrm{O}-2,6-\mathrm{Me}-\mathrm{C}_{6} \mathrm{H}_{3}\right)(\mathrm{THF})$ (9) and ${ }^{\mathrm{Me} 2} \mathrm{SB}\left({ }^{\mathrm{tBu}} \mathrm{N}, \mathrm{I}^{*}\right) \mathrm{Al}\left(\mathrm{O}-2,4-{ }^{t} \mathrm{Bu}-\mathrm{C}_{6} \mathrm{H}_{3}\right)(\mathrm{THF})(\mathbf{1 0})$ are reported. All complexes were characterised by NMR spectroscopy. Solid-state structures of 2-4, 6 and 8-10 were determined by X-ray crystallography. Ringopening polymerisation of L- and rac-lactide using all complexes with the exception of $\mathbf{6}$ show first-order dependence on monomer concentration and produced polylactide with unimodal molecular weight distribution. First-order dependence on catalyst concentration was determined from L-lactide polymerisation using 4 and 9. Moderately heterotactic polylactide $\left(P_{r}=0.53-0.68\right)$ was achieved from rac-lactide polymerisation using 4, 5, 7 and $\mathbf{9}$. The effects of the metal centre ( $\mathrm{Sc}$ and $\mathrm{Al}$ ), the amido substituent ('Pr, ${ }^{t} \mathrm{Bu}$, ${ }^{n} \mathrm{Bu}$ and $\left.\mathrm{Ph}\right)$ and the aryloxide initiating group $\left(\mathrm{O}-2,6-\mathrm{Me}-\mathrm{C}_{6} \mathrm{H}_{3}, \mathrm{O}-2,6-{ }^{i} \mathrm{Pr}-\mathrm{C}_{6} \mathrm{H}_{3}\right.$ and $\left.\mathrm{O}-2,4-{ }^{t} \mathrm{Bu}-\mathrm{C}_{6} \mathrm{H}_{3}\right)$ on the catalytic activity are discussed.
\end{abstract}

Received 8th July 2020,

Accepted 29th August 2020

DOI: $10.1039 /$ d0py00980f

rsc.li/polymers cene CGCs containing a bridged amido-cyclopentadienyl $\left\{\mathrm{C}_{5} \mathrm{H}_{4}\left({ }^{t} \mathrm{Bu}\right)^{-}\right\}$ligand. ${ }^{4}$ Since then, several synthesis and applications of CGCs containing different substituted cyclopentadienyl, indenyl and fluorenyl groups, coordinating heteroatoms, ansa-linkages and metal centres were reported in the literature, ${ }^{5}$ particularly Group 4 CGCs for olefin polymerisations. ${ }^{6}$ The enhanced ability of Group 4 CGCs for ethylene polymerisation and (co)polymerisation of ethylene and $\alpha$-olefins is ascribed to a smaller $\mathrm{Cp}_{\text {centroid }}-\mathrm{M}-\mathrm{N}$ bite angle than the typical $\mathrm{Cp}_{\text {centroid }}-\mathrm{M}-\mathrm{C} \mathrm{p}_{\text {centroid }}$ in metallocene systems and a reduced tendency to undergo chain transfer reactions, resulting in high molecular weight polymers. ${ }^{3 a, 7}$ More electron deficient metal centres (an amido moiety formerly donates two electrons less than a cyclopentadienyl-based ligand) also promote olefin insertion into the metal-carbon bond and increase reactivity. ${ }^{3 a, 7}$ Due to the higher thermal stability than related metallocenes, higher polymerisation temperatures are permitted by alkyl or dialkyl CGCs. ${ }^{8}$ The indenyl ligand $\left(\mathrm{C}_{9} \mathrm{H}_{7}{ }^{-}\right.$, Ind, I $)$has been studied as an alternative to the cyclopentadienyl ligand $\left(\mathrm{C}_{5} \mathrm{H}_{5}{ }^{-}, \mathrm{Cp}\right) .{ }^{6 h, 8 a, 9}$ The indenyl ring slippage from $\eta^{5}$ to $\eta^{3}$-hapticity was observed when the formal number of metal electrons increased by two, resulting in a higher activity of ligand substitution reactions of electronically unsaturated complexes compared to their analogous Cp complexes. ${ }^{10}$ Permethylation of the indenyl ring has been proposed to increase steric congestion around the metal centre compared to the indenyl ligand, and afford kinetic stability to the 


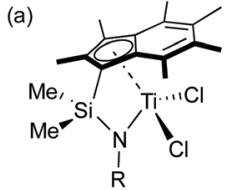

$\mathrm{R}={ }^{t} \mathrm{Bu},{ }^{n} \mathrm{Bu},{ }^{i} \mathrm{Pr}, \mathrm{Ph}$,

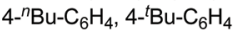
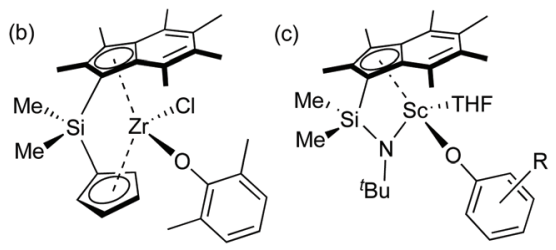

$\mathrm{R}=2,6-^{-} \mathrm{Pr}$ and $2,4-{ }^{t} \mathrm{Bu}$
Chart 1 Group 3 and 4 permethylindenyl complexes reported by O'Hare and co-workers. ${ }^{12-14}$

metal-Ind* bond. ${ }^{11}$ Group 4 CGCs with variation of the amido moieties, ansa-bridges and permethylindenyl ligands have been developed by O'Hare and co-workers from ${ }^{\mathrm{Me} 2} \mathrm{SB}\left({ }^{t \mathrm{Bu}} \mathrm{N}, \mathrm{I}^{*}\right)$ $\mathrm{TiCl}_{2}$ (Chart 1a). ${ }^{12}$ These complexes are efficient for slurryphase ethylene polymerisation and ethylene/1-hexene and ethylene/styrene (co)polymerisations. Another family of ansabridged permethylindenyl Group 4 metallocenes were used as catalysts for slurry-phase ethylene polymerisation and lactide polymerisation (Chart 1b). ${ }^{13}$ A bimodal molecular weight distribution was observed from poly(L-lactide) obtained from ROP of L-LA using an ansa-bridged permethylindenyl zirconium dichloride complex in the presence of benzyl alcohol. ${ }^{13 b}$ We recently reported constrained geometry scandium permethylindenyl aryloxide complexes, ${ }^{\mathrm{Me} 2} \mathrm{SB}\left({ }^{t \mathrm{Bu}} \mathrm{N}, \mathrm{I}^{*}\right) \mathrm{Sc}\left(\mathrm{O}-2,6-{ }^{i} \mathrm{Pr}-\mathrm{C}_{6} \mathrm{H}_{3}\right)$ (THF) and ${ }^{\mathrm{Me} 2} \mathrm{SB}\left({ }^{t \mathrm{Bu}} \mathrm{N}, \mathrm{I}^{*}\right) \mathrm{Sc}\left(\mathrm{O}-2,4{ }^{t}{ }^{\mathrm{Bu}}-\mathrm{C}_{6} \mathrm{H}_{3}\right)(\mathrm{THF})$, as initiators for lactide polymerisation (Chart 1c). ${ }^{14}$ The single-site nature of scandium permethylindenyl CGCs leads to high molecular weight polylactide and unimodal molecular weight distribution $\left(M_{\mathrm{w}} / M_{\mathrm{n}}<1.2\right)$.

In this work, constrained geometry permethylindenyl complexes with variation of the metal centre ( $\mathrm{Sc}$ and $\mathrm{Al}$ ), an amido substituent $\left({ }^{i} \mathrm{Pr},{ }^{t} \mathrm{Bu},{ }^{n} \mathrm{Bu}\right.$ and $\left.\mathrm{Ph}\right)$ and an aryloxide initiating group (O-2,6-Me- $\mathrm{C}_{6} \mathrm{H}_{3}$, O-2,6- ${ }^{i} \mathrm{Pr}-\mathrm{C}_{6} \mathrm{H}_{3}$ and O-2,4- ${ }^{t} \mathrm{Bu}-\mathrm{C}_{6} \mathrm{H}_{3}$ ) were synthesised and studied as catalysts for polymerisation of $\mathrm{L}^{-}$and rac-lactide.

\section{Results and discussion}

\section{Synthesis of constrained geometry scandium complexes}

Reactions of ${ }^{\mathrm{Me} 2} \mathrm{SB}\left({ }^{\mathrm{R}} \mathrm{N}, \mathrm{I}^{*}\right) \mathrm{Li}_{2}(\mathrm{THF}){ }_{x}\left(\mathrm{R}={ }^{i} \mathrm{Pr},{ }^{n} \mathrm{Bu}\right.$ and $\left.\mathrm{Ph}\right)$ and $\mathrm{ScCl}_{3} \cdot 3 \mathrm{THF}$ in a $1: 1$ molar ratio were carried out in benzene at

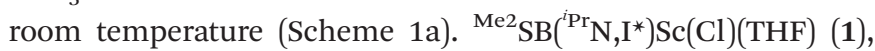
${ }^{\mathrm{Me} 2} \mathrm{SB}\left({ }^{n \mathrm{Bu}} \mathrm{N}, \mathrm{I}^{*}\right) \mathrm{Sc}(\mathrm{Cl})(\mathrm{THF})(2)$ and ${ }^{\mathrm{Me} 2} \mathrm{SB}\left({ }^{\mathrm{Ph}} \mathrm{N}, \mathrm{I}^{*}\right) \mathrm{Sc}(\mathrm{Cl})(\mathrm{THF})(3)$ were isolated as yellow solids in 35, 6 and $41 \%$ yield, respectively. A series of aryloxide complexes ${ }^{\mathrm{Me} 2} \mathrm{SB}\left({ }^{i \mathrm{Pr}} \mathrm{N}, \mathrm{I}^{*}\right) \mathrm{Sc}\left(\mathrm{O}-2,6{ }^{i}{ }^{i} \mathrm{Pr}-\right.$ $\left.\mathrm{C}_{6} \mathrm{H}_{3}\right)(\mathrm{THF}) \quad(4),{ }^{\mathrm{Me} 2} \mathrm{SB}\left({ }^{i}{ }^{i} \mathrm{~N}, \mathrm{I}^{*}\right) \mathrm{Sc}\left(\mathrm{O}-2,4-{ }^{t} \mathrm{Bu}-\mathrm{C}_{6} \mathrm{H}_{3}\right)(\mathrm{THF}) \quad$ (5), ${ }^{\mathrm{Me} 2} \mathrm{SB}\left({ }^{n \mathrm{Bu}} \mathrm{N}, \mathrm{I}^{*}\right) \mathrm{Sc}\left(\mathrm{O}-2,6-{ }^{i} \mathrm{Pr}-\mathrm{C}_{6} \mathrm{H}_{3}\right)$ (THF) (6) and ${ }^{\mathrm{Me} 2} \mathrm{SB}\left({ }^{\mathrm{Ph}} \mathrm{N}, \mathrm{I}^{*}\right) \mathrm{Sc}$ $\left(\mathrm{O}-2,6-{ }^{i}{ }^{\mathrm{Pr}}-\mathrm{C}_{6} \mathrm{H}_{3}\right)(\mathrm{THF})$ (7) were synthesised from reactions between complexes 1-3 and appropriate potassium aryloxide salts (Scheme 1b). Complexes 4, 5 and 7 were isolated in 44, 34 and $41 \%$ yields, respectively. The ${ }^{1} \mathrm{H}$ NMR spectra of 1-7 (see ESI $\dagger$ ) show five singlets corresponding to the indenyl methyl protons at $1.50-3.00 \mathrm{ppm}$ and two singlets corresponding to
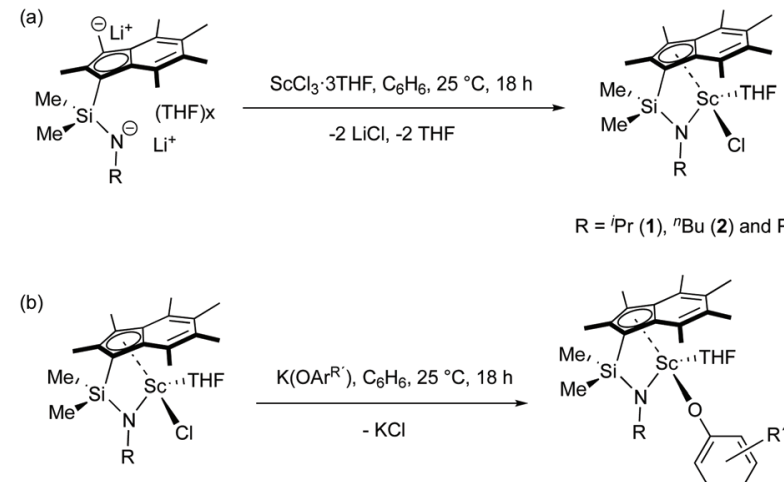

$\mathrm{R}={ }^{i} \operatorname{Pr}(\mathbf{1}),{ }^{n} \mathrm{Bu}(\mathbf{2})$ and $\mathrm{Ph}(\mathbf{3})$

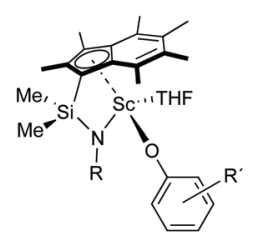

$R={ }^{i} \operatorname{Pr}$ with $R^{\prime}=2,6-{ }^{-} \operatorname{Pr}(4)$ $\mathrm{R}={ }^{\mathrm{i}} \mathrm{Pr}$ with $\mathrm{R}^{\prime}=2,4-\mathrm{t}^{\mathrm{t}} \mathrm{Bu}(\mathbf{5})$ $\mathrm{R}={ }^{n} \mathrm{Bu}$ with $\mathrm{R}^{\prime}=2,6-\mathrm{Pr}(6)$ $R=P h$ with $R^{\prime}=2,6^{-} \operatorname{Pr}(7)$

Scheme 1 (a) Synthesis of ${ }^{\mathrm{Me} 2} \mathrm{SB}\left({ }^{\mathrm{R}} \mathrm{N}, \mathrm{I}^{*}\right) \mathrm{ScCl}(\mathrm{THF})(1-3)$ and (b) ${ }^{\mathrm{Me} 2} \mathrm{SB}$ $\left({ }^{\mathrm{R}} \mathrm{N}, \mathrm{I}^{*}\right) \mathrm{Sc}\left(\mathrm{OAr} \mathrm{r}^{\mathrm{R}}\right)(\mathrm{THF})(4-7)$.

the silylmethyl groups between $0.50-1.20 \mathrm{ppm}$. Resonances of methylene protons of a THF molecule coordinated to the metal centre were also observed. The X-ray crystal structures of complexes 2-4 and $\mathbf{6}$ have been determined and are shown in Fig. 1. Selected bond lengths and angles are listed in Table 1.

Single crystals suitable of X-ray diffraction studies of 2 and 3 were grown at room temperature of saturated benzene solution and pentane solution, respectively, and found to crystallise in the space group $P \overline{1}$ and $C 2 / c$. The solid-state structures of 2 and 3 are dimeric, consisting of two chloride-bridged scandium centres. Each scandium centre has a distorted square pyramidal geometry, evidenced by the $\tau_{5}$ values of 0.22 and 0.02 for 2 and $3,{ }^{15}$ respectively, with $\eta^{5}$-coordination with the $\mathrm{C}_{9} \mathrm{Me}_{6}$ ring. The oxygen of the THF ligand and nitrogen of the amido group also coordinate to the metal centre. The Sc (1) $-I^{*}$ cent bond length of $3(2.1845(1) \AA)$ is slightly longer than 2 (2.1836(1) A) due to the increased steric bulk of the phenyl group on the amido ligand compared with the $n$-butyl group. The two $\mathrm{C}_{9} \mathrm{Me}_{6}$ rings on 2 have a trans arrangement while those on 3 have a cis arrangement. Therefore, the plane containing scandium and chlorine atoms of 2 is planar while that of 3 is puckered with an interplanar angle of $24.3^{\circ}$ (Fig. S61 $\dagger$ ) in order to reduce steric repulsion between the $\mathrm{C}_{9} \mathrm{Me}_{6}$ rings.

The average Sc-Cl bond lengths of 2 and 3 (2.5987 and $2.5894 \AA$ ) are comparable to those observed from reported complexes. ${ }^{16}$ Compared to 3, an analogous Cp-based scandium CGC $\left[{ }^{\mathrm{Me} 2} \mathrm{SB}\left({ }^{\mathrm{Ph}} \mathrm{N}, \mathrm{C}_{5} \mathrm{Me}_{4}\right) \mathrm{Sc}(\mu-\mathrm{Cl})(\mathrm{THF})\right]_{2}$ reported by Hou et al. has comparable Sc-Cl $(2.545 \AA), \mathrm{Sc}-\mathrm{Cp}_{\text {cent }}(2.171 \AA), \mathrm{Sc}-\mathrm{N}$

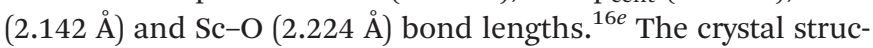
ture of $\left[\mathrm{Cp}_{2} \mathrm{Sc}(\mu-\mathrm{Cl})\right]_{2}$ was reported with a $\mathrm{Sc}-\mathrm{Cl}$ distance of $2.575 \AA^{16 a}$ Another THF-free complex $\left[\mathrm{Sc}\left(\mathrm{N}_{2} \mathrm{~N}^{\mathrm{C} 3, \mathrm{Me}}\right) \mathrm{Sc}(\mu-\mathrm{Cl})\right]_{2}$ where $\mathrm{N}_{2} \mathrm{~N}^{\mathrm{C} 3, \mathrm{Me}}=\operatorname{MeN}\left\{\left(\mathrm{CH}_{2}\right)_{3} \mathrm{NSiMe}_{3}\right\}_{2}{ }^{1 a}$ was reported with a Sc-Cl bond length of $2.5685 \AA^{16 c}\left[\mathrm{Sc}\left(\mathrm{C}_{8} \mathrm{H}_{8}\right)(\mu-\mathrm{Cl})(\mathrm{THF})\right]_{2}{ }^{16 g}$ and $\left[\mathrm{Sc}\left(\mathrm{C}_{8} \mathrm{H}_{6}\left(1,4-\mathrm{SiMe}_{3}\right)_{2}\right)(\mu-\mathrm{Cl})\right]_{2}(\mathrm{THF})^{16 b}$ were reported with Sc-Cl bond distances of 2.5972 and $2.5155 \AA$, respectively. A scandium chloride complex containing $\mathrm{C}_{5} \mathrm{Me}_{4} \mathrm{SiMe}_{2} \mathrm{CH}_{2} \mathrm{Ch}_{2} \mathrm{Ph}$ ligand has a tetrameric structure with the average $\mathrm{Sc}-\mathrm{Cl}$ bond 
(a)

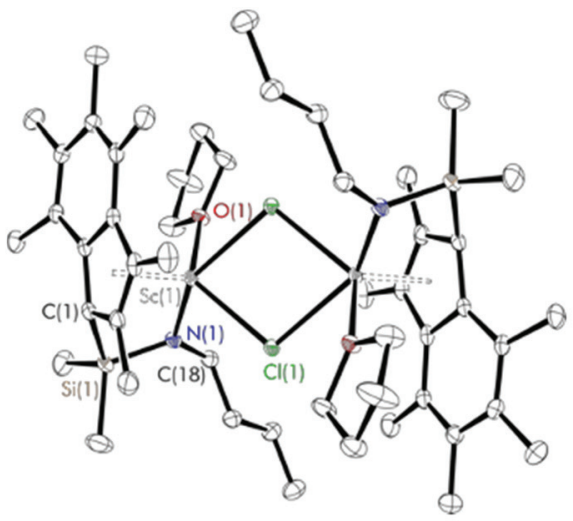

(c)

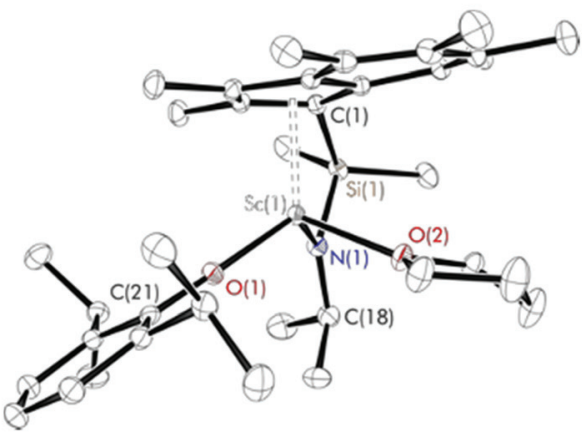

(b)

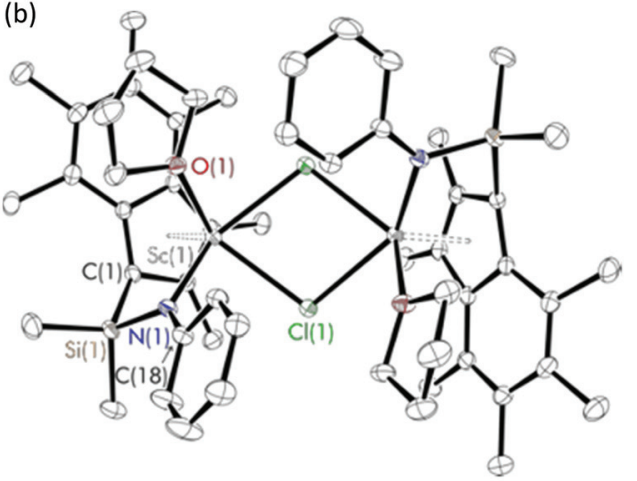

(d)

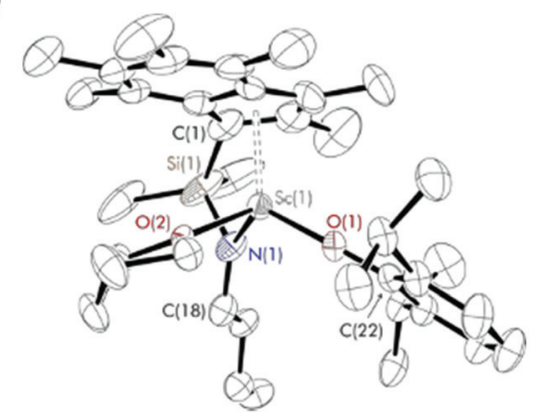

Fig. 1 Solid-state structures of (a) ${ }^{\mathrm{Me} 2} \mathrm{SB}\left({ }^{n \mathrm{BB}} \mathrm{N}, \mathrm{I}^{*}\right) \mathrm{Sc}(\mathrm{Cl})(\mathrm{THF})$ (2), (b) ${ }^{\mathrm{Me} 2} \mathrm{SB}\left({ }^{\mathrm{Ph}} \mathrm{N}, I^{*}\right) \mathrm{Sc}(\mathrm{Cl})(\mathrm{THF})$ (3), (c) ${ }^{\mathrm{Me} 2} \mathrm{SB}\left({ }^{i} \mathrm{Pr} \mathrm{N}, \mathrm{I}^{*}\right) \mathrm{Sc}\left(\mathrm{O}-2,6-^{i} \mathrm{Pr}-\mathrm{C}_{6} \mathrm{H}_{3}\right)(\mathrm{THF})(4)$ and (d) ${ }^{\mathrm{Me} 2} \mathrm{SB}\left({ }^{n \mathrm{Bu}} \mathrm{N}, \mathrm{I}^{*}\right) \mathrm{Sc}\left(\mathrm{O}-2,6-{ }^{i} \mathrm{Pr}-\mathrm{C}_{6} \mathrm{H}_{3}\right)(\mathrm{THF})$ (6). Ellipsoids are drawn at the $30 \%$ probability level and $\mathrm{H}$ atoms omitted for clarity.

Table 1 Selected bond lengths (Å) and angles $\left({ }^{\circ}\right)$ for ${ }^{\mathrm{Me} 2} \mathrm{SB}\left({ }^{n B u} \mathrm{~N}, I^{*}\right) \mathrm{Sc}(\mathrm{Cl})(\mathrm{THF})(2)$ and ${ }^{\mathrm{Me} 2} \mathrm{SB}\left({ }^{\mathrm{Ph}} \mathrm{N}, \mathrm{I}^{*}\right) \mathrm{Sc}(\mathrm{Cl})(\mathrm{THF})(3),{ }^{\mathrm{Me} 2} \mathrm{SB}\left({ }^{\mathrm{Pr}} \mathrm{N}, \mathrm{I}^{*}\right) \mathrm{Sc}\left(\mathrm{O}-2,6-\mathrm{Pr}-\mathrm{C}_{6} \mathrm{H}_{3}\right)$ (THF) (4), ${ }^{\mathrm{Me} 2} \mathrm{SB}\left({ }^{n \mathrm{Bu}} \mathrm{N}, \mathrm{I}^{*}\right) \mathrm{Sc}\left(\mathrm{O}-2,6-{ }^{i} \mathrm{Pr}-\mathrm{C}_{6} \mathrm{H}_{3}\right)(\mathrm{THF})(6)$ and ${ }^{\mathrm{Me} 2} \mathrm{SB}\left({ }^{\mathrm{tBu}} \mathrm{N}, \mathrm{I}^{*}\right) \mathrm{Sc}\left(\mathrm{O}-2,6-{ }^{i} \mathrm{Pr}-\mathrm{C}_{6} \mathrm{H}_{3}\right)(\mathrm{THF})^{14}$ (E.S.D.s are given in parentheses)

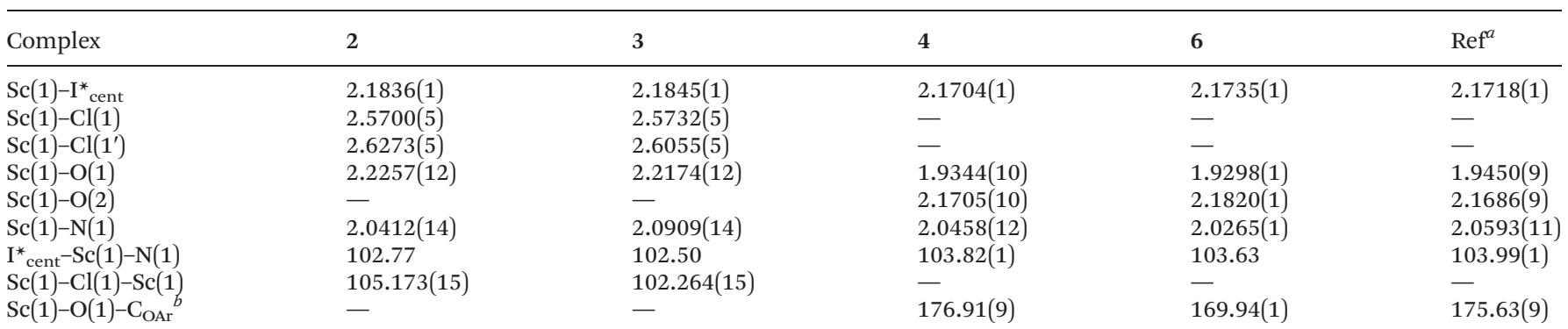

${ }^{a \mathrm{Me} 2} \mathrm{SB}\left({ }^{t \mathrm{Bu}} \mathrm{N}, \mathrm{I}^{*}\right) \mathrm{Sc}\left(\mathrm{O}-2,6-{ }^{i} \mathrm{Pr}_{-} \mathrm{C}_{6} \mathrm{H}_{3}\right)(\mathrm{THF}) \cdot{ }^{14}{ }^{b} \mathrm{Sc}(1)-\mathrm{O}(1)-\mathrm{C}(21)$ for 4 and $\mathrm{Sc}(1)-\mathrm{O}(1)-\mathrm{C}(22)$ for 6.

length of $2.5243 \AA{ }^{16 f}$ The crystal structures of 2 and 3 also show similar $\mathrm{Sc}(1)-\mathrm{I}^{*}$ cent bond lengths to those of cyclopentadienyl based scandium chloride complexes (2.12-2.18 $){ }^{16 a, d, f}$ In contrast to the dimeric structure of 2 and 3 , their titanium analogues were described as monomeric with no THF ligand coordinated to the metal centre. ${ }^{12 a}$ The Ti-Cp $\mathrm{T}_{\text {cent }}(2.03 \AA)$ and Ti-N (1.89-1.94 ̊) bond lengths of ${ }^{\mathrm{Me} 2} \mathrm{SB}\left({ }^{\mathrm{R}} \mathrm{N}, \mathrm{I}^{*}\right) \mathrm{TiCl}_{2}\left(\mathrm{R}={ }^{t} \mathrm{Bu}\right.$, ${ }^{i}$ Pr and $\left.4{ }^{t}{ }^{t} \mathrm{Bu}-\mathrm{C}_{6} \mathrm{H}_{4}\right)$ are smaller than those of 2 and 3.

Solid-state structures of ${ }^{\mathrm{Me} 2} \mathrm{SB}\left({ }^{i} \mathrm{Pr} \mathrm{N}, \mathrm{I}^{*}\right) \mathrm{Sc}\left(\mathrm{O}-2,6-{ }^{i} \mathrm{Pr}^{-} \mathrm{C}_{6} \mathrm{H}_{3}\right)$ (THF) (4) and ${ }^{\mathrm{Me} 2} \mathrm{SB}\left({ }^{n \mathrm{Bu}} \mathrm{N}, \mathrm{I}^{*}\right) \mathrm{Sc}\left(\mathrm{O}-2,6-{ }^{i} \mathrm{Pr}-\mathrm{C}_{6} \mathrm{H}_{3}\right)$ (THF) (6) are monomeric with a distorted tetrahedral geometry at the scandium centre, indicated by the $\tau_{4}$ parameters of 0.89 and 0.86 for 4 and $6,{ }^{17}$ respectively. The bond distances of $\mathrm{Sc}(1)-\mathrm{O}(1)$ and $\mathrm{Sc}(1)-\mathrm{N}(1)$ of 4 (1.9344(10) and 2.0458(12) Å) are slightly longer than those of 6 (1.9298(1) and 2.0265(1) $\AA$ ). The bond lengths of $\mathrm{Sc}(1)-\mathrm{I}^{*}$ cent $, \mathrm{Sc}(1)-\mathrm{O}(1), \mathrm{Sc}(1)-\mathrm{O}(2)$ and $\mathrm{Sc}(1)-\mathrm{N}(1)$ of 4 and 6 are comparable to those previously reported from ${ }^{\mathrm{Me} 2} \mathrm{SB}\left({ }^{t \mathrm{Bu}} \mathrm{N}, \mathrm{I}^{*}\right) \mathrm{Sc}\left(\mathrm{O}-2,6{ }^{i}{ }^{\mathrm{Pr}}-\mathrm{C}_{6} \mathrm{H}_{3}\right)(\mathrm{THF}){ }^{14}$ (Table 1$)$. As a consequence of the less sterically demanding ${ }^{n} \mathrm{Bu}$ group on the amido ligand of 6 compared to the ${ }^{i} \mathrm{Pr}$ group on $\mathbf{4}$ or ${ }^{t} \mathrm{Bu}$ group on ${ }^{\mathrm{Me} 2} \mathrm{SB}\left({ }^{t \mathrm{Bu}} \mathrm{N}, \mathrm{I}^{*}\right) \mathrm{Sc}\left(\mathrm{O}-2,6{ }^{-}{ }^{i} \mathrm{Pr}-\mathrm{C}_{6} \mathrm{H}_{3}\right)(\mathrm{THF})$, the aryloxide group is more oriented towards the amido ligand on 6 than 4 or ${ }^{\mathrm{Me} 2} \mathrm{SB}\left({ }^{\mathrm{tBu}} \mathrm{N}, \mathrm{I}^{*}\right) \mathrm{Sc}\left(\mathrm{O}-2,6{ }^{i}{ }^{i} \mathrm{Pr}-\mathrm{C}_{6} \mathrm{H}_{3}\right)(\mathrm{THF})$. Hence, the $\left.\left.\mathrm{Sc}(1)\right)-\mathrm{O}(1)\right)-$ $\mathrm{C}_{\mathrm{OAr}}$ angle of 169.94(1) in 6 is considerably smaller than that of $176.91(9)^{\circ}$ in 4 and $175.63(9)^{\circ}$ in ${ }^{\mathrm{Me} 2} \mathrm{SB}\left({ }^{t \mathrm{Bu}} \mathrm{N}, \mathrm{I}^{*}\right) \mathrm{Sc}\left(\mathrm{O}-2,{ }^{-}{ }^{i}{ }^{i} \mathrm{Pr}-\right.$ $\left.\mathrm{C}_{6} \mathrm{H}_{3}\right)(\mathrm{THF})$. 


\section{Synthesis of constrained geometry aluminium complexes}

${ }^{\mathrm{Me} 2} \mathrm{SB}\left({ }^{\mathrm{tBu}} \mathrm{N}, \mathrm{I}^{*}\right) \mathrm{Al}(\mathrm{Cl})(\mathrm{THF})(\mathbf{8})$ was prepared in $49 \%$ yield via the salt elimination reaction of ${ }^{\mathrm{Me} 2} \mathrm{SB}\left({ }^{t \mathrm{Bu}} \mathrm{N}, \mathrm{I}^{*}\right) \mathrm{Li}_{2}(\mathrm{THF})_{x}$ and $\mathrm{AlCl}_{3} \cdot \mathrm{THF}$ in benzene at room temperature (Scheme 2a). The aryloxide complexes, ${ }^{\mathrm{Me} 2} \mathrm{SB}\left({ }^{t \mathrm{Bu}} \mathrm{N}, \mathrm{I}^{*}\right) \mathrm{Al}\left(\mathrm{O}-2,6-\mathrm{Me}-\mathrm{C}_{6} \mathrm{H}_{3}\right)(\mathrm{THF})(\mathbf{9})$

(a)
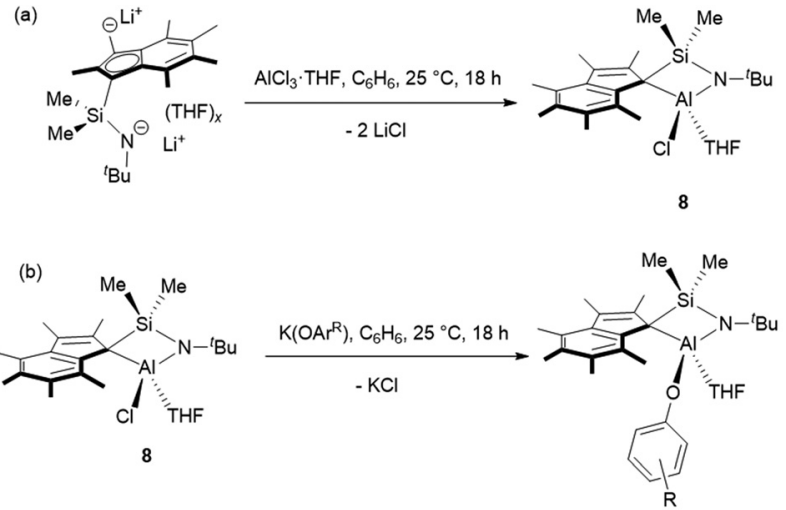

$\mathrm{R}=2,6-\mathrm{Me}(9)$ and $2,4-^{-} \mathrm{Bu}(10)$

Scheme 2 (a) Synthesis of ${ }^{\mathrm{Me}_{2}} \mathrm{SB}\left({ }^{\mathrm{tBu}} \mathrm{N}, \mathrm{I}^{*}\right) \mathrm{Al}(\mathrm{Cl})(\mathrm{THF})(8),(\mathrm{b}){ }^{\mathrm{Me}_{2}} \mathrm{SB}\left({ }^{\mathrm{tBu}} \mathrm{N}, \mathrm{I}^{*}\right)$ $\mathrm{Al}\left(\mathrm{O}-2,6-\mathrm{Me}-\mathrm{C}_{6} \mathrm{H}_{3}\right)(\mathrm{THF})$ (9) and ${ }^{\mathrm{Me}_{2}} \mathrm{SB}\left({ }^{\mathrm{tBu}} \mathrm{N}, \mathrm{I}^{*}\right) \mathrm{Al}\left(\mathrm{O}-2,4-{ }^{t} \mathrm{Bu}-\mathrm{C}_{6} \mathrm{H}_{3}\right)(\mathrm{THF})$ (10).

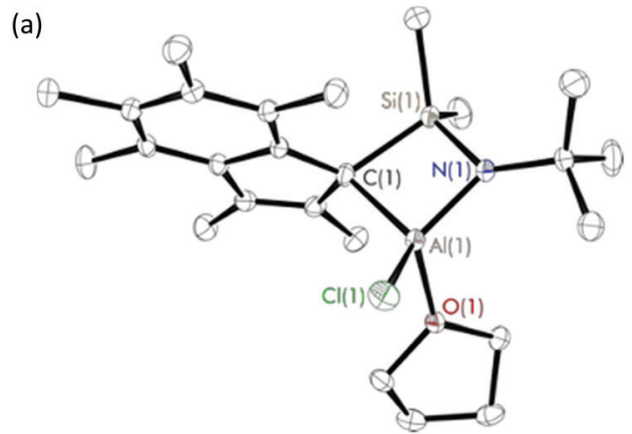

and ${ }^{\mathrm{Me} 2} \mathrm{SB}\left({ }^{t \mathrm{Bu}} \mathrm{N}, \mathrm{I}^{*}\right) \mathrm{Al}\left(\mathrm{O}-2,4{ }^{t}{ }^{\mathrm{Bu}}-\mathrm{C}_{6} \mathrm{H}_{3}\right)(\mathrm{THF})$ (10), were synthesised by reactions of 8 and $\mathrm{K}\left(\mathrm{O}-2,6-\mathrm{Me}-\mathrm{C}_{6} \mathrm{H}_{3}\right)$ or $\mathrm{K}\left(\mathrm{O}-2,4-{ }^{t} \mathrm{Bu}-\mathrm{C}_{6} \mathrm{H}_{3}\right)$ in benzene at room temperature (Scheme 2b), and were isolated in 41 and $24 \%$ yield, respect-

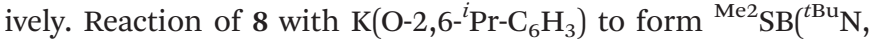
$\left.\mathrm{I}^{*}\right) \mathrm{Al}\left(\mathrm{O}-2,6{ }^{i}{ }^{i} \mathrm{Pr}-\mathrm{C}_{6} \mathrm{H}_{3}\right)(\mathrm{THF})$ was carried out. However, several attempts to isolate clean product of ${ }^{\mathrm{Me} 2} \mathrm{SB}\left({ }^{t \mathrm{Bu}} \mathrm{N}, \mathrm{I}^{*}\right) \mathrm{Al}\left(\mathrm{O}-2,6-{ }^{i} \mathrm{Pr}-\right.$ $\mathrm{C}_{6} \mathrm{H}_{3}$ )(THF) were unsuccessful. The ${ }^{1} \mathrm{H}$ NMR spectra of 8-10 (Fig. S18, S20 and S22†) show two sets of resonances corresponding to a mixture of two isomers.

Diffraction-quality crystals were grown from a concentrated benzene solution of $\mathbf{8}$ and $\mathbf{9}$ and a pentane solution of $\mathbf{1 0}$ at room temperature. X-ray crystal structures of 8 and 9 (Fig. 2) were obtained for one isomer, while for complex 10 (Fig. 3), both isomers were obtained (Fig. S22 $\dagger$ ). In contrast to the scandium constrained geometry complexes (1-7), 8-10 display $\sigma$-instead of $\pi$-bonding interactions between the metal centre and $\mathrm{C}_{9} \mathrm{Me}_{6}$ ring due to the absence of accepting d-orbitals on the aluminium centre. The hapticity of one between the $\mathrm{C}_{9} \mathrm{Me}_{6}$ ring and the metal centre is consistent with the known Group $13^{18}$ and $15^{19}$ cyclopentadienyl constrained geometry complexes reported in literature. Cowley et al. synthesised and crystallographically characterised complexes ${ }^{\mathrm{Me} 2} \mathrm{SB}\left({ }^{t \mathrm{Bu}} \mathrm{N}, \mathrm{C}_{5} \mathrm{Me}_{4}\right) \mathrm{M}$ $\left(\mathrm{CH}_{3}\right)(\mathrm{THF})(\mathrm{M}=\mathrm{Al}$ and $\mathrm{Ga}) .{ }^{18 b}$ The $\mathrm{C}_{5} \mathrm{Me}_{4}$ ring possesses a

(b)

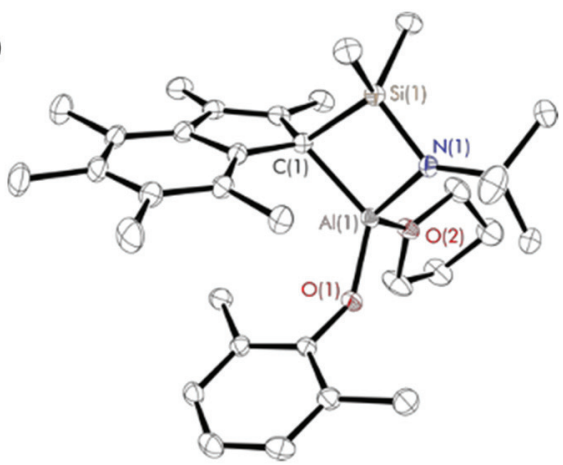

Fig. 2 Solid-state structures of (a) ${ }^{\mathrm{Me} 2} \mathrm{SB}\left({ }^{\mathrm{B} u} \mathrm{~N}, I^{*}\right) \mathrm{Al}(\mathrm{Cl})(\mathrm{THF})(8)$ and (b) ${ }^{\mathrm{Me} 2} \mathrm{SB}\left({ }^{\mathrm{B} u} \mathrm{~N}, I^{*}\right) \mathrm{Al}\left(\mathrm{O}-2,6-\mathrm{Me}-\mathrm{C}_{6} \mathrm{H}_{3}\right)(\mathrm{THF})$ (9). Ellipsoids are drawn at the $30 \%$ probability level and $\mathrm{H}$ atoms omitted for clarity.

(a)

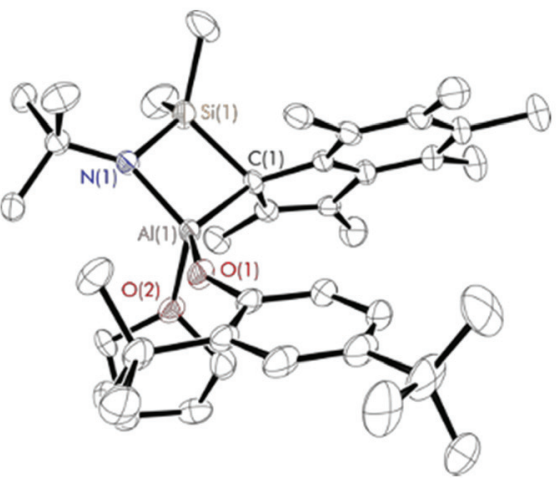

(b)

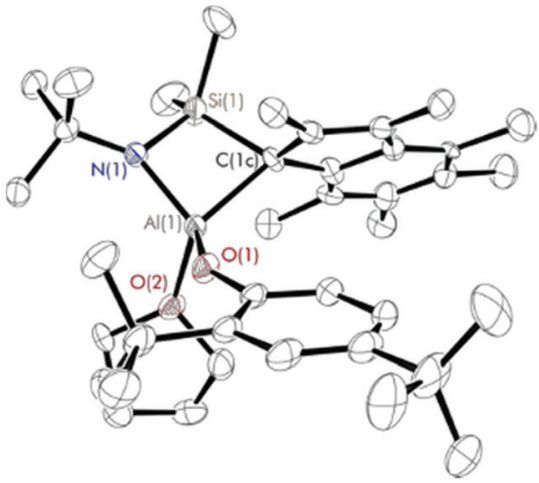

Fig. 3 Solid-state structures of isomer 1 (a) and 2 (b) of ${ }^{\mathrm{Me} 2} \mathrm{SB}\left({ }^{\mathrm{tBu}} \mathrm{N}, \mathrm{I}^{\star}\right) \mathrm{Al}\left(\mathrm{O}-2,4-{ }^{t} \mathrm{Bu}-\mathrm{C}_{6} \mathrm{H}_{3}\right)(\mathrm{THF})(10)$. Ellipsoids are drawn at the $30 \%$ probability level and $\mathrm{H}$ atoms omitted for clarity. 
localised diene structure, and the $\sigma$-attachment occurs at the metal centre at an $\alpha$ position with respect to the $\mathrm{SiMe}_{2}$ group affording a five-membered ring $\mathrm{M}-\mathrm{C}-\mathrm{C}-\mathrm{Si}-\mathrm{N}$ ring. The solidstate structures of $\mathbf{8 - 1 0}$ show $\sigma$-bonds between the aluminium centre and the carbon on the $\mathrm{C}_{9} \mathrm{Me}_{6}$ ring adjacent to $\mathrm{SiMe}_{2}$ group, and the nitrogen of the ${ }^{t \mathrm{Bu}} \mathrm{N}$ moiety linked between the metal centre and the $\mathrm{SiMe}_{2}$ group. The four-membered ring of $\mathrm{Al}-\mathrm{C}-\mathrm{Si}-\mathrm{N}$ is perpendicular to the $\mathrm{C}_{9} \mathrm{Me}_{6}$ ring. Distorted tetrahedral geometry at the aluminium centre was observed, confirmed by the $\tau_{4}$ values of $0.81,0.76$ and 0.72 for $\mathbf{8 , 9}$ and 10, respectively. ${ }^{17}$ The presence of the four-membered ring species was reported by Rieger et al. for the solid-state structure of aluminium constrained geometry cyclopentadienyl complex containing the lutidinyl moiety. ${ }^{18 c}$

In contrast to the analogous dimeric scandium complexes (2 and 3), 8 was obtained as a monomer with smaller $\mathrm{M}(1)-\mathrm{Cl}$ (1) bond length of 2.1375(7) $\AA$ than those in 2 and 3 (2.5700-2.5732 $\AA$ ). A similar trend was observed for the aryloxide complexes 9 and 10 with the shorter $\mathrm{M}(1)-\mathrm{O}(1), \mathrm{M}(1)-\mathrm{O}$ (2) and $\mathrm{M}(1)-\mathrm{N}(1)$ distances comparing to those of $\mathbf{4}$ and $\mathbf{6}$. The $\mathrm{C}(1)-\mathrm{Al}(1)-\mathrm{O}(1)$ and $\mathrm{Al}(1)-\mathrm{O}(1)-\mathrm{C}_{\mathrm{OAr}}$ angles of 9 (124.96(8) and $\left.143.72(14)^{\circ}\right)$ are considerably smaller than those of $\mathbf{1 0}$ (133.04(13) and $\left.147.2(2)^{\circ}\right)$ as a result of the less sterically-hindered aryloxide group on $\mathbf{9}$.

X-ray crystal structures of $\mathbf{1 0}$ show two components of the complex in which the $\mathrm{C}_{9} \mathrm{Me}_{6}$ ring featuring in two different positions (Fig. 3, Table S6 $\dagger$ ). The $\mathrm{C}_{9} \mathrm{Me}_{6}$ ring in isomer 1 and isomer 2 are labelled as $\mathrm{C}(1)-\mathrm{C}(9)$ and $\mathrm{C}(1 \mathrm{c})-\mathrm{C}(9 \mathrm{c})$, respectively. The direction of the six-membered ring on the $\mathrm{C}_{9} \mathrm{Me}_{6}$ ring of isomer $\mathbf{1}$ is at the front side of the five-membered ring, while that of isomer 2 is at the backside of the five-membered ring. Bond lengths and angles of the two isomers of $\mathbf{1 0}$ are shown in Table 2. The significant differences between the $\mathrm{C}(1)-\mathrm{Al}(1)-\mathrm{O}(1)$ and $\mathrm{C}(1)-\mathrm{Al}(1)-\mathrm{O}(2)$ angles in isomer 1 and those in isomer 2 were observed, and reflect a different conformation of the $\mathrm{C}_{9} \mathrm{Me}_{6}$ ring found in the solid state structures of 10. The ratio of these two components from the crystal structure of $10(59: 41)$ is consistent with those from the solution ${ }^{1} \mathrm{H}$ NMR spectrum (55:45) (Fig. S22 $\dagger$ ). Two isomers found in the ${ }^{1} \mathrm{H}$ NMR spectra of 8 and 9 (Fig. S18 and S20†) are also proposed to be attributed to the different $\mathrm{C}_{9} \mathrm{Me}_{6}$ ring position.
Polymerisation of $\mathrm{L}^{-}$and rac-lactide using scandium complexes ${ }^{\mathrm{Me} 2} \mathrm{SB}\left({ }^{i}{ }^{\mathrm{Pr}} \mathrm{N}, \mathrm{I}^{*}\right) \mathrm{Sc}(\mathrm{Cl})(\mathrm{THF}) \quad$ (1), ${ }^{\mathrm{Me} 2} \mathrm{SB}\left({ }^{n \mathrm{Bu}} \mathrm{N}, \mathrm{I}^{*}\right) \mathrm{Sc}(\mathrm{Cl})(\mathrm{THF}) \quad$ (2) and ${ }^{\mathrm{Me} 2} \mathrm{SB}\left({ }^{\mathrm{Ph}} \mathrm{N}, \mathrm{I}^{*}\right) \mathrm{Sc}(\mathrm{Cl})(\mathrm{THF})$ (3) were tested as initiators for the polymerisation of L-lactide in the presence of benzyl alcohol. In situ protonolysis is commonly used for lactide polymerisation catalysed by scandium alkyl, ${ }^{20}$ amide $^{21}$ or chloride $^{13 b, 14}$ complexes. It is hypothesised that benzyl alcohol reacts in situ with the chloride ligand of 1-3 to form the benzyloxide group which initiates the polymerisation via coordination-insertion mechanism. Under the same conditions, the polymerisation rate follows the order of $1>2>3$ with $k_{\text {obs }}$ values of $1.21,0.89$ and $0.57 \mathrm{~h}^{-1}$, respectively (Table 3 , entries 1-3). This indicates the effect of increasing nucleophilicity of the amido substituent on polymerisation activity $\left({ }^{i} \mathrm{Pr}>{ }^{n} \mathrm{Bu}>\right.$ $\mathrm{Ph})$. The introduction of the electron donating substituent on the amido ligand can increase the Lewis acidity of the metal centre, which is favourable for scandium-alkoxide bond cleavage. Kinetic measurements show a first-order dependence on L-lactide concentration (Fig. 4). No initiation period was observed with high monomer conversion reached within 2-4.5 h. Polymer molecular weights determined by GPC are in a fair agreement with those calculated for one chain per metal centre, and narrow $M_{\mathrm{w}} / M_{\mathrm{n}}$ values (1.17) were observed. The presence of polylactide terminated with $\mathrm{OCH}_{2} \mathrm{Ph}$ end-group was observed in the ${ }^{1} \mathrm{H}$ NMR spectrum (Fig. S51†). End-group analysis by MALDI-ToF mass spectrometry (Fig. S56†) also shows peaks corresponding to polylactide with $\mathrm{OCH}_{2} \mathrm{Ph}$ and $\mathrm{OH}$ end-groups and peak envelopes separated by $\Delta(\mathrm{m} / \mathrm{z})$ of 72.0 Da indicating intermolecular transesterification.

Complexes 1-3 exhibit superior performance compared to reported scandium monoamide or monoalkyl complexes. ${ }^{20 c, 21 a}$ Carpentier et al. reported scandium alkyl complex supported by phenoxy-aminopyridinate ligand for polymerisation of racLA with ${ }^{i} \mathrm{PrOH}$ as co-initiator $\left([\mathrm{rac}-\mathrm{LA}]_{0}:[\mathrm{Sc}]_{0}:\left[{ }^{i} \mathrm{PrOH}\right]_{0}=\right.$ $500: 1: 1) .^{20 c}$ Only $4 \%$ conversion was achieved after $1.5 \mathrm{~h}$ in toluene at $60{ }^{\circ} \mathrm{C}$. Okuda et al. used bis(phenolato)scandium amide complex with ${ }^{i} \mathrm{PrOH}$ to polymerise $83 \%$ of 300 equivalents of rac-lactide after $72 \mathrm{~h} .^{21 a}$

${ }^{\mathrm{Me} 2} \mathrm{SB}\left({ }^{i \mathrm{Pr}} \mathrm{N}, \mathrm{I}^{*}\right) \mathrm{Sc}\left(\mathrm{O}-2,6{ }^{i}{ }^{i} \mathrm{Pr}-\mathrm{C}_{6} \mathrm{H}_{3}\right)$ (THF) (4), ${ }^{\mathrm{Me} 2} \mathrm{SB}\left({ }^{i}{ }^{i} \mathrm{~N}, \mathrm{I}^{*}\right) \mathrm{Sc}$ $\left(\mathrm{O}-2,4-{ }^{t}{ }^{\mathrm{Bu}}-\mathrm{C}_{6} \mathrm{H}_{3}\right)$ (THF) (5) and ${ }^{\mathrm{Me} 2} \mathrm{SB}\left({ }^{\mathrm{Ph}} \mathrm{N}, \mathrm{I}^{*}\right) \mathrm{Sc}\left(\mathrm{O}-2,6-{ }^{i} \mathrm{Pr}-\mathrm{C}_{6} \mathrm{H}_{3}\right)$ (THF) (7) were used as initiators for ring-opening polymeris-

Table 2 Selected bond lengths (Å) and angles $\left({ }^{\circ}\right)$ for ${ }^{\mathrm{Me} 2} \mathrm{SB}\left({ }^{\mathrm{tBu}} \mathrm{N}, \mathrm{I}^{*}\right) \mathrm{Al}(\mathrm{Cl})(\mathrm{THF})(8),{ }^{\mathrm{Me} 2} \mathrm{SB}\left({ }^{\mathrm{tBu}} \mathrm{N}, \mathrm{I}^{*}\right) \mathrm{Al}\left(\mathrm{O}-2,6-\mathrm{Me}-\mathrm{C}_{6} \mathrm{H}_{3}\right)(\mathrm{THF})(9)$ and isomer 1 and 2 of ${ }^{\mathrm{Me} 2} \mathrm{SB}\left({ }^{\mathrm{B} u} \mathrm{~N}, I^{*}\right) \mathrm{Al}\left(\mathrm{O}-2,4-{ }^{t} \mathrm{Bu}-\mathrm{C}_{6} \mathrm{H}_{3}\right)(\mathrm{THF})(10)(\mathrm{E} . \mathrm{S} . \mathrm{D} . \mathrm{s}$ are given in parentheses)

\begin{tabular}{lllll}
\hline Complex & $\mathbf{8}$ & $\mathbf{9}$ & $\mathbf{1 0}$ (Isomer 1) \\
\hline $\mathrm{Al}(1)-\mathrm{Cl}(1)$ & $2.1375(7)$ & - & - & $1.712(2)$ \\
$\mathrm{Al}(1)-\mathrm{O}(1)$ & $1.8600(13)$ & $1.7150(15)$ & $1.880(2)$ & $\mathbf{1 0}$ (Isomer 2) \\
$\mathrm{Al}(1)-\mathrm{O}(2)$ & - & $1.8917(15)$ & $1.815(2)$ & $1.712(2)$ \\
$\mathrm{Al}(1)-\mathrm{N}(1)$ & $1.8047(15)$ & $1.8221(18)$ & $2.051(4)$ & $1.880(2)$ \\
$\mathrm{Al}(1)-\mathrm{C}(1)$ & $2.0257(18)$ & $2.027(2)$ & $133.04(13)$ & $1.815(2)$ \\
$\mathrm{C}(1)-\mathrm{Al}(1)-\mathrm{O}(1)$ & $110.78(7)$ & $124.96(8)$ & $101.68(15)$ & $111.5(2)$ \\
$\mathrm{C}(1)-\mathrm{Al}(1)-\mathrm{O}(2)$ & - & $115.06(8)$ & $89.13(14)$ & $129.1(3)$ \\
$\mathrm{C}(1)-\mathrm{Al}(1)-\mathrm{N}(1)$ & $89.06(7)$ & $88.36(8)$ & $81.13(16)$ & $86.8(3)$ \\
$\mathrm{Si}(1)-\mathrm{C}(1)-\mathrm{Al}(1)$ & $82.08(7)$ & $82.67(8)$ & $94.87(14)$ & \\
$\mathrm{C}(1)-\mathrm{Si}(1)-\mathrm{N}(1)$ & $94.17(7)$ & $94.34(8)$ & $147.2(2)$ &
\end{tabular}


Table 3 Selected polymerisation data using complexes $1-5$ and $7^{a}$

\begin{tabular}{|c|c|c|c|c|c|c|c|c|c|c|c|}
\hline Entry & Complex & LA & {$[\mathrm{LA}]_{0}:[\mathrm{Sc}]_{0}$} & $T\left({ }^{\circ} \mathrm{C}\right)$ & $t(\mathrm{~h})$ & Conv. $^{b}(\%)$ & $k_{\mathrm{obs}}\left(\mathrm{h}^{-1}\right)$ & $M_{\mathrm{n}}(\mathrm{GPC})^{c}\left(\mathrm{~g} \mathrm{~mol}^{-1}\right)$ & $M_{\mathrm{n}}(\mathrm{Calcd})^{d}\left(\mathrm{~g} \mathrm{~mol}^{-1}\right)$ & $M_{\mathrm{w}} / M_{\mathrm{n}}$ & $P_{\mathrm{r}}$ \\
\hline 1 & 1 & $\mathrm{~L}^{-}$ & $400: 1$ & 70 & 2 & 90 & $1.21 \pm 0.03$ & 42290 & 51984 & 1.17 & 0.00 \\
\hline 2 & 2 & $\mathrm{~L}^{-}$ & $400: 1$ & 70 & 3 & 91 & $0.89 \pm 0.02$ & 44920 & 52560 & 1.17 & 0.00 \\
\hline 3 & 3 & $\mathrm{~L}^{-}$ & $400: 1$ & 70 & 4.5 & 90 & $0.57 \pm 0.02$ & 39810 & 51984 & 1.16 & 0.00 \\
\hline 4 & 4 & $\mathrm{~L}^{-}$ & $600: 1$ & 70 & 2.25 & 87 & $1.18 \pm 0.05$ & 69700 & 99319 & 1.16 & 0.00 \\
\hline 5 & 4 & $\mathrm{~L}^{-}$ & $800: 1$ & 70 & 3 & 86 & $0.81 \pm 0.01$ & 103670 & 150618 & 1.14 & 0.00 \\
\hline 6 & 4 & $\mathrm{~L}^{-}$ & $1000: 1$ & 70 & 3.5 & 85 & $0.66 \pm 0.02$ & 91500 & 122663 & 1.13 & 0.00 \\
\hline 7 & 4 & $\mathrm{~L}^{-}$ & $1200: 1$ & 70 & 5 & 87 & $0.46 \pm 0.01$ & 103670 & 150618 & 1.14 & 0.00 \\
\hline 8 & 4 & $\mathrm{~L}^{-}$ & $1000: 1$ & 60 & 8 & 91 & $0.34 \pm 0.01$ & 105980 & 130309 & 1.09 & 0.00 \\
\hline 9 & 4 & $\mathrm{~L}^{-}$ & $1000: 1$ & 80 & 2.5 & 92 & $1.35 \pm 0.04$ & 85090 & 132750 & 1.18 & 0.00 \\
\hline 10 & 4 & $\mathrm{~L}^{-}$ & $1000: 1$ & 100 & 1.25 & 90 & $2.68 \pm 0.09$ & 75280 & 129868 & 1.19 & 0.00 \\
\hline 11 & 4 & rac- & $1000: 1$ & 70 & 2.5 & 93 & $1.27 \pm 0.04$ & 83100 & 134191 & 1.21 & 0.59 \\
\hline 12 & 5 & $\mathrm{~L}^{-}$ & $1000: 1$ & 70 & 0.5 & 91 & $6.32 \pm 0.37$ & 77560 & 131337 & 1.18 & 0.00 \\
\hline 13 & 5 & rac- & $1000: 1$ & 70 & 0.5 & 91 & $7.40 \pm 0.50$ & 64540 & 131337 & 1.23 & 0.68 \\
\hline 14 & 7 & $\mathrm{~L}^{-}$ & $1000: 1$ & 70 & 4 & 84 & $0.48 \pm 0.01$ & 69570 & 121222 & 1.15 & 0.00 \\
\hline 15 & 7 & rac- & $1000: 1$ & 70 & 3.5 & 86 & $0.58 \pm 0.01$ & 64820 & 124104 & 1.17 & 0.63 \\
\hline
\end{tabular}

${ }^{a}$ Conditions for ROP using 1-3: $[\mathrm{LA}]_{0}:[\mathrm{Sc}]_{0}:[\mathrm{BnOH}]_{0}=400: 1: 1,[\mathrm{LA}]_{0}=0.5 \mathrm{M}, 7.0 \mathrm{~mL}$ toluene and conditions for ROP using 4, 5 and 7: $[\mathrm{LA}]_{0}:[\mathrm{Sc}]_{0}$ as stated, $[\mathrm{LA}]_{0}=0.5 \mathrm{M}, 7.0 \mathrm{~mL}$ toluene. ${ }^{b}$ Measured by ${ }^{1} \mathrm{H}$ NMR spectroscopic analyses. ${ }^{c}$ Determined by GPC in THF against PS standards using the appropriate Mark-Houwink corrections. ${ }^{22}{ }^{d}$ Calculated $M_{\mathrm{n}}$ for PLA synthesised by using $1-3=\operatorname{conv} .(\%) \times 400 \times 144.1+108.1$, calculated $M_{\mathrm{n}}$ for PLA synthesised with 4 and $7=$ conv. $(\%) \times[\mathrm{LA}]_{0}:[\mathrm{Sc}]_{0} \times 144.1+178.1$ and calculated $M_{\mathrm{n}}$ for PLA synthesised by using $5=$ conv. $(\%) \times[\mathrm{LA}]_{0}:[\mathrm{Sc}]_{0} \times 144.1+206.2$.

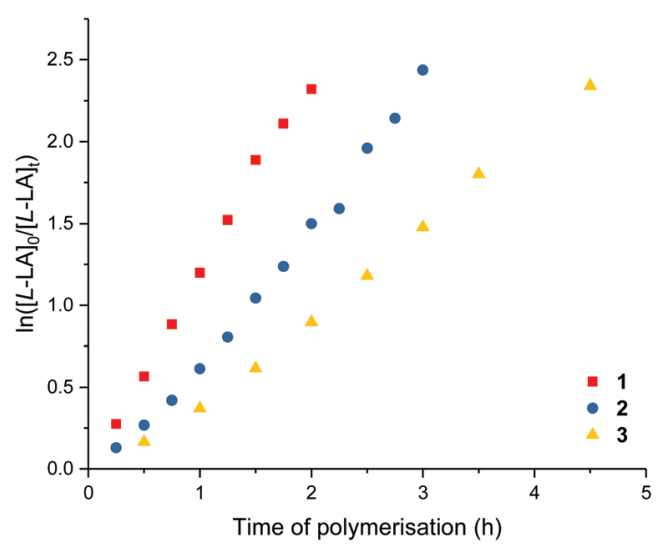

Fig. 4 Plots of $\ln \left([L-L A]_{0} /[L-L A]_{t}\right) \quad$ vs. time of polymerisation. Red squares: ROP of Llactide using $1, k_{\mathrm{obs}}=1.21 \pm 0.03 \mathrm{~h}^{-1}, R^{2}=0.995$. Blue circles: ROP of L-lactide using $2, k_{\text {obs }}=0.89 \pm 0.02 \mathrm{~h}^{-1}, R^{2}=0.994$. Yellow triangles: ROP of L-lactide using $3, k_{\text {obs }}=0.57 \pm 0.02 \mathrm{~h}^{-1}, R^{2}=$ 0.992. Conditions: $[\mathrm{L}-\mathrm{LA}]_{0}:[\mathrm{SC}]_{0}:[\mathrm{BnOH}]_{0}=400: 1: 1,[\mathrm{~L}-\mathrm{LA}]_{0}=0.5 \mathrm{M}$, $7.0 \mathrm{~mL}$ toluene at $70{ }^{\circ} \mathrm{C}$.

ation of $\mathrm{L}^{-}$and rac-lactide (Table 3, entries 4-15). First-order dependence on monomer concentration was observed in all cases, evidenced by linear plots of $\ln \left([\mathrm{L}-\mathrm{LA}]_{0} /[\mathrm{L}-\mathrm{LA}]_{t}\right) v s$. time (see ESI $\dagger$ ). Under the same conditions, complexes $\mathbf{4}$ and $\mathbf{5}$ exhibited greater polymerisation rate than 7 suggesting the effect of the electron donating ability of amido substituent on polymerisation activity $\left({ }^{i} \mathrm{Pr}>\mathrm{Ph}\right)$. Despite bearing the same amido substituent $\left({ }^{i} \mathrm{Pr}\right)$, polymerisations using $\mathbf{5}$ are significantly greater than those using $\mathbf{4}$ which could be attributed to the 2,4-substitution pattern of the aryloxide ligand of $\mathbf{5}$, relative to the 2,6-substitution of $\mathbf{4}$, resulting in reduced steric crowding around the metal centre and an increased rate of lactide insertion into the metal-aryloxide bond in the initiation step. ${ }^{23}$ For $\mathbf{4 , 5}$ and 7, the polymerisation rate of rac- lactide is faster than those of L-lactide, suggesting a preference for racemic linkages. The polymer tacticity measured by homonuclear decoupled ${ }^{1} \mathrm{H}\left\{{ }^{1} \mathrm{H}\right\}$ NMR spectroscopy showed that $\mathbf{4 , 5}$ and 7 produced slightly heterotactic polylactide with $P_{\mathrm{r}}$ values of $0.59-0.68$, suggesting the initiators favour racemic enchainment with chain-end control, where the next monomer to insert has an opposing stereocentre from the last monomer. This suggests that the substituent on the amido group has marginal influence on the stereoselectivity. Isotactic pure poly (L-lactide) was formed without epimerisation during polymerisation of L-lactide with 4,5 and 7 , confirmed by a single resonance in the methine region of the ${ }^{1} \mathrm{H}\left\{{ }^{1} \mathrm{H}\right\}$ NMR spectra (see ESI†). Catalytic studies of ${ }^{\mathrm{Me} 2} \mathrm{SB}\left({ }^{n{ }^{n \mathrm{u}}} \mathrm{N}, \mathrm{I}^{*}\right) \mathrm{Sc}\left(\mathrm{O}-2,6-{ }^{i} \mathrm{Pr}^{-} \mathrm{C}_{6} \mathrm{H}_{3}\right)$ (THF) (6) were not performed as adequate quantities could not be obtained in suitable yield.

Detailed kinetic studies were performed using 4 . Polymerisation of L-lactide with 4 using different catalyst loading was carried out at $70{ }^{\circ} \mathrm{C}$ in toluene. Concentration of L-lactide was maintained at $0.5 \mathrm{M}$ while that of 4 was varied giving the monomer to catalyst ratio of $600,800,1000$ and 1200. The polymerisation data are summarised in Table 3 (entries 4-7). First-order dependence on L-lactide was observed from all conditions evidenced by linear plots of $\ln \left([\mathrm{L}-\mathrm{LA}]_{0} /\right.$ $\left.[\mathrm{L}-\mathrm{LA}]_{t}\right) v s$. time with an induction period of $0.5 \mathrm{~h}$ (Fig. 5). The gradient of 0.89 is indicative of first-order dependence on the concentration of 4 (Fig. 6). The propagation rate constant $\left(k_{\mathrm{p}}\right)$ of $1120 \pm 29 \mathrm{M}^{-1} \mathrm{~h}^{-1}$ was calculated from plot of $k_{\text {obs }} v s$. $[4]_{0}$ (Fig. 7). The overall rate law was determined as $-\mathrm{d}[\mathrm{L}-\mathrm{LA}] / \mathrm{dt}=$ $k_{\mathrm{p}}[\mathrm{L}-\mathrm{LA}][\mathrm{4}]$.

The ${ }^{1} \mathrm{H}$ NMR spectra of oligomers synthesised by $\mathbf{4}$ and $\mathbf{5}$ (Fig. S52 and S53†) show signals corresponding to O-2,6 ${ }^{i} \mathrm{Pr}-$ $\mathrm{C}_{6} \mathrm{H}_{3}$ and $\mathrm{O}-2,4{ }^{t}{ }^{t} \mathrm{Bu}-\mathrm{C}_{6} \mathrm{H}_{3}$ end-groups, suggesting that the ROP of L-lactide proceeds via a coordination-insertion mechanism (Scheme S1†). The presence of polylactide with ${ }^{i} \mathrm{Pr} \mathrm{NH}$ and $\mathrm{OH}$ end-groups was observed from MALDI-ToF mass spectra 


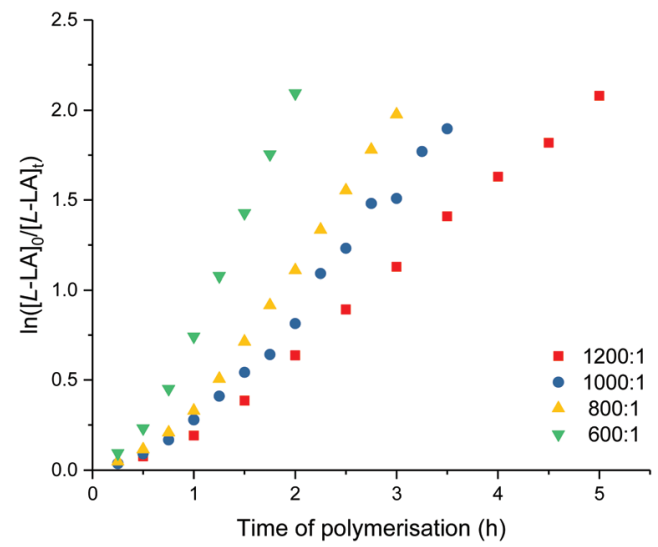

Fig. 5 Plots of $\ln \left([L-L A]_{O} /[L-L A]_{t}\right)$ vs. time of polymerisation. ROP of L-lactide using 4. [L-LA $]_{0} /[\mathrm{SC}]_{0}=1200$, red square: $k_{\text {obs }}=0.46 \pm 0.01 \mathrm{~h}^{-1}$, $R^{2}=0.996$. $[\mathrm{L}-\mathrm{LA}]_{0} /[\mathrm{SC}]_{0}=1000$, blue circle: $k_{\text {obs }}=0.66 \pm 0.02 \mathrm{~h}^{-1}, R^{2}=$ 0.989 . $[\mathrm{L}-\mathrm{LA}]_{0} /[\mathrm{SC}]_{0}=800$, yellow triangle: $k_{\mathrm{obs}}=0.81 \pm 0.01 \mathrm{~h}^{-1}, R^{2}=$ 0.996 . $[\mathrm{L}-\mathrm{LA}]_{0} /[\mathrm{SC}]_{0}=600$, green down triangle: $k_{\mathrm{obs}}=1.18 \pm 0.05 \mathrm{~h}^{-1}$, $R^{2}=0.985$. Conditions: $[\mathrm{L}-\mathrm{LA}]_{0}=0.5 \mathrm{M}, 7.0 \mathrm{~mL}$ toluene at $70^{\circ} \mathrm{C}$.

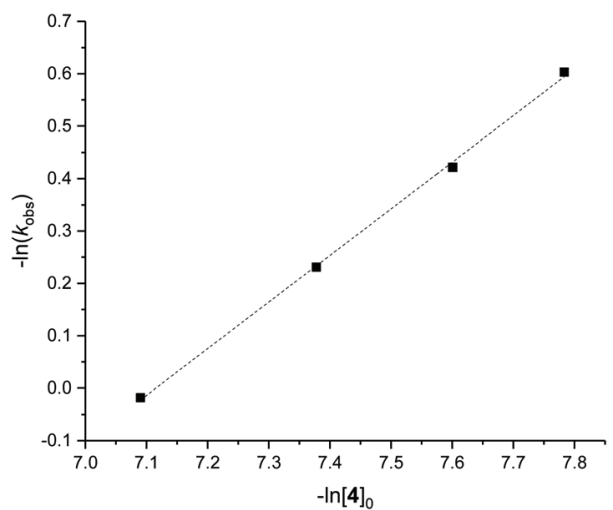

Fig. 6 Plot of $-\ln \left(k_{\text {obs }}\right)$ vs. $-\ln \left([4]_{0}\right)$ for ROP of L-LA using 4 shows that the order of reaction with respect to $[4]_{0}$ is equal to $0.89 \pm 0.02$. $R^{2}=0.999$. Conditions: $[\mathrm{L}-\mathrm{LA}]_{0}=0.5 \mathrm{M}, 7.0 \mathrm{~mL}$ toluene at $70^{\circ} \mathrm{C}$.

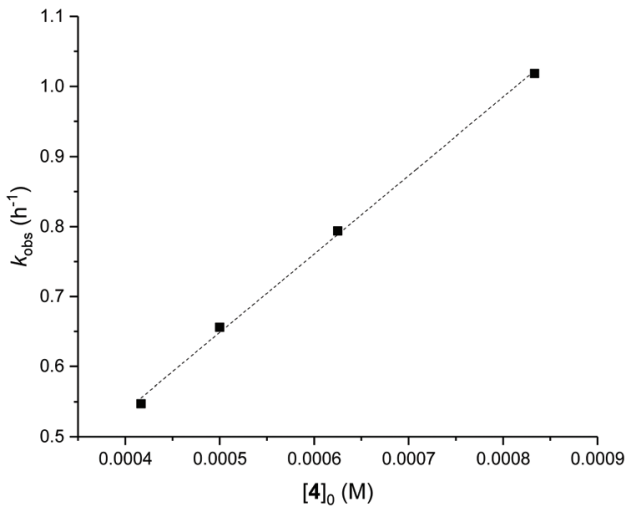

Fig. 7 Plot of $k_{\text {obs }} v s$. [4] $]_{0}$ for ROP of L-LA using $4, k_{\mathrm{p}}=1120 \pm 29 \mathrm{M}^{-1} \mathrm{~h}^{-1}$. $R^{2}=0.998$. Conditions: $[\mathrm{L}-\mathrm{LA}]_{0}=0.5 \mathrm{M}, 7.0 \mathrm{~mL}$ toluene at $70^{\circ} \mathrm{C}$.
(Fig. S57 and S58†), suggesting the role of the amido ligand as an initiator. Peaks corresponding to cyclic polylactide and a repeating unit of $\Delta(\mathrm{m} / \mathrm{z})=72.0$ Da between peak envelopes were also observed, indicating an occurrence of intra- and intermolecular transesterification reactions, respectively. Therefore, the considerably lower than calculated $M_{\mathrm{n}}$ (GPC) values could be attributed to double-site initiator from the amido and aryloxide ligands.

Complexes 4, 5 and 7 show better activity for L-lactide polymerisation with high monomer loading (600-1200) compared to other metallocene catalysts in the literature. ${ }^{13 b, 24}$ Zirconocene bis(ester enolate) complex $\left(\mathrm{Ph}_{2} \mathrm{C}(\mathrm{Cp}, \mathrm{Flu}) \mathrm{Zr}[\mathrm{OC}\right.$ $\left.\left.(\mathrm{O} i \mathrm{Pr})=\mathrm{CMe}_{2}\right]_{2}\right)$ reported by Chen et al. polymerised 200 equivalents of L-lactide (toluene, $80{ }^{\circ} \mathrm{C}$ ) up to $85 \%$ within $5 \mathrm{~h}^{24 a}$ Other zirconocene complexes $\left(\text { rac- } \mathrm{C}_{2} \mathrm{H}_{4} \text { (Ind) }\right)_{2} \mathrm{Zr}[\mathrm{OC}$ $\left.\left(\mathrm{O}^{i} \mathrm{Pr}\right)=\mathrm{CMe}_{2}\right]_{2}$ and $\left.\mathrm{Cp}_{2} \mathrm{Zr}\left[\mathrm{OC}\left(\mathrm{O}^{i} \mathrm{Pr}\right)=\mathrm{CMe}_{2}\right]_{2}\right)$ from the same research group were reported to be poorly active under the same conditions. ${ }^{24 a} \mathrm{~A}$ series of $\mathrm{Cp}$ and Ind-based group $4 \mathrm{com}-$ plexes reported by O'Hare et al. were found to be active in L-lactide polymerisation. ${ }^{24 b}$ (Ind) ${ }_{2} \mathrm{ZrMe}\left(\mathrm{O}^{t} \mathrm{Bu}\right)$ was the fastest catalyst with the $k_{\mathrm{obs}}$ values of 0.317 and $0.293 \mathrm{~h}^{-1}$ for polymerisation of $\mathrm{L}^{-}$and rac-lactide (50 equivalents) at $100{ }^{\circ} \mathrm{C}$ in chloroform- $d_{1}$, respectively. ${ }^{\mathrm{Me} 2} \mathrm{SB}\left(\mathrm{Cp}, \mathrm{I}^{*}\right) \mathrm{ZrCl}\left(\mathrm{O}-2,6-\mathrm{Me}-\mathrm{C}_{6} \mathrm{H}_{3}\right)$ presented a second-order dependence on L-lactide concentration $\left(k_{\mathrm{obs}}=3.23 \mathrm{M}^{-1} \mathrm{~h}^{-1}\right)$ for the polymerisation with $[\mathrm{L}-\mathrm{LA}]_{0}:[\mathrm{Zr}]_{0}:[\mathrm{BnOH}]_{0}$ ratio of $50: 1: 2$ in chloroform- $d$ at $80{ }^{\circ} \mathrm{C} .{ }^{13 b}$ Okuda et al. reported the yttrocene complex $\mathrm{Li}\left[\left(\mathrm{Me}_{2} \mathrm{Si}\right.\right.$ $\left.\left.\left(\mathrm{Cp}, \mathrm{NC}_{2} \mathrm{H}_{4} \mathrm{OMe}\right)\right)_{2} \mathrm{Y}\right] .{ }^{24 c}$ L-Lactide polymerisation in toluene at $75{ }^{\circ} \mathrm{C}$ with $[\mathrm{L}-\mathrm{LA}]_{0}:[\mathrm{Y}]_{0}$ ratio of 127 gave polymer after $2 \mathrm{~h}$ with $M_{\mathrm{n}}$ value double that expected and $M_{\mathrm{w}} / M_{\mathrm{n}}$ of 1.44. Cui et al. reported $r a c$-lactide polymerisation using scandium aryloxide complex supported by a pentadentate $\left(\mathrm{N}_{2} \mathrm{O}_{3}\right)$ salen-type ligand in THF at room temperature $(71 \%$ conversion, $2 \mathrm{~h}) .{ }^{25}$ Scandium alkoxide complexes containing a phosphasalen ligand were found to be inactive for rac-lactide polymerisation attributed to the formation of an unreactive single-lactide insertion product. ${ }^{26}$

The effect of temperature on L-lactide polymerisation activity using 4 was studied with polymerisation temperature varied from $60-100{ }^{\circ} \mathrm{C}$ (Table 3, and Fig. 8). The enthalpy of activation $\left(\Delta H^{\ddagger}\right)$ of $53 \mathrm{~kJ} \mathrm{~mol}^{-1}$ and entropy of activation $\left(\Delta S^{\ddagger}\right)$ of $-95 \mathrm{~J} \mathrm{~mol}^{-1} \mathrm{~K}^{-1}$ were calculated from an Eyring plot of $\ln \left(k_{\text {obs }} / T\right) v s .1 / T$ (Fig. S76 $\dagger$ ). These values are comparable to those reported, and suggest the ordered transition state in a coordination-insertion mechanism. ${ }^{14,27}$ As expected, the polymerisation activity increased at higher temperatures. $M_{\mathrm{w}} / M_{\mathrm{n}}$ values and discrepancy between $M_{\mathrm{n}}$ (GPC) values and those calculated were observed to increase with increased temperature, attributed to transesterification reactions.

\section{Polymerisation of $\mathrm{L}^{-}$and rac-lactide using aluminium complexes}

${ }^{\mathrm{Me} 2} \mathrm{SB}\left({ }^{t \mathrm{Bu}} \mathrm{N}, \mathrm{I}^{*}\right) \mathrm{Al}(\mathrm{Cl})(\mathrm{THF})$ (8) was found to be less active than the analogous scandium chloride complexes (1-3) for L-lactide polymerisation in the presence of benzyl alcohol even at higher polymerisation temperature $\left(100^{\circ} \mathrm{C}\right)$ and lower ratio of 


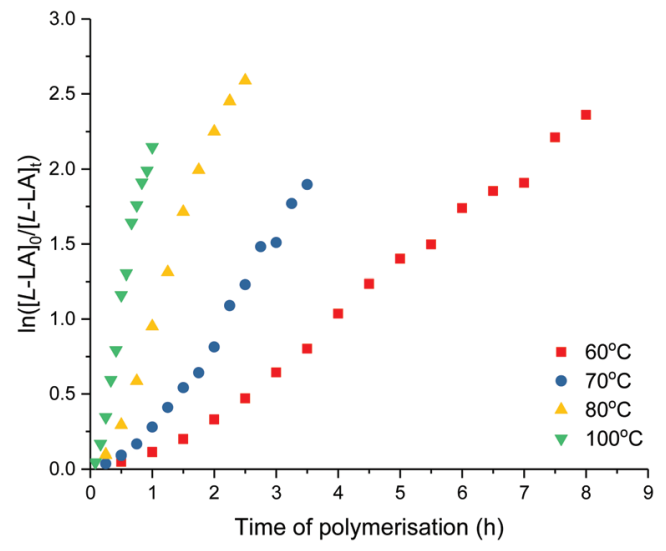

Fig. 8 Plots of $\ln \left([L-L A]_{0} /[L-L A]_{t}\right)$ vs. time of polymerisation. ROP of Llactide using $4.60{ }^{\circ} \mathrm{C}$, red square: $k_{\text {obs }}=0.34 \pm 0.01 \mathrm{~h}^{-1}, R^{2}=0.995$. $70{ }^{\circ} \mathrm{C}$, blue circle: $k_{\text {obs }}=0.66 \pm 0.02 \mathrm{~h}^{-1}, R^{2}=0.989 .80^{\circ} \mathrm{C}$, yellow triangle: $k_{\text {obs }}=1.35 \pm 0.04 \mathrm{~h}^{-1}, R^{2}=0.996 .100^{\circ} \mathrm{C}$, green down triangle: $k_{\text {obs }}=2.68 \pm 0.09 \mathrm{~h}^{-1}, R^{2}=0.989$. Conditions: $[\mathrm{L}-\mathrm{LA}]_{0}=0.5 \mathrm{M}$, $[\mathrm{L}-\mathrm{LA}]_{0}:[4]_{0}=1000,7.0 \mathrm{~mL}$ toluene.

$[\mathrm{L}-\mathrm{LA}]_{0}:[\mathrm{Al}]_{0}:[\mathrm{BnOH}]_{0} \quad(100: 1: 1)$. L-Lactide conversion reached $55 \%$ after $7.5 \mathrm{~h}$ which first-order dependence on L-lactide concentration was observed $\left(k_{\text {obs }}=0.11 \mathrm{~h}^{-1}\right.$, Fig. S84†). The polymerisations were quenched after $23 \mathrm{~h}$ with $80 \%$ conversion. The experimental $M_{\mathrm{n}}$ value (17 $600 \mathrm{~g} \mathrm{~mol}^{-1}$ ) is higher than that calculated for one chain per metal centre (11636 $\mathrm{g} \mathrm{mol}^{-1}$ ) with moderate $M_{\mathrm{w}} / M_{\mathrm{n}}$ value of $1.37 . \mathrm{OCH}_{2} \mathrm{Ph}$ terminated polylactide was observed from the ${ }^{1} \mathrm{H}$ NMR (Fig. S54 $\dagger$ ) and MALDI-ToF mass spectra (Fig. S59†).

${ }^{\mathrm{Me} 2} \mathrm{SB}\left({ }^{\mathrm{tBu}} \mathrm{N}, \mathrm{I}^{*}\right) \mathrm{Al}\left(\mathrm{O}-2,6-\mathrm{Me}-\mathrm{C}_{6} \mathrm{H}_{3}\right)(\mathrm{THF})(9)$ and ${ }^{\mathrm{Me} 2} \mathrm{SB}\left({ }^{t \mathrm{Bu}} \mathrm{N}, \mathrm{I}^{*}\right)$ $\mathrm{Al}\left(\mathrm{O}-2,4-{ }^{t} \mathrm{Bu}-\mathrm{C}_{6} \mathrm{H}_{3}\right)(\mathrm{THF})$ (10) show comparable activity for polymerisation of $\mathrm{L}$-lactide at $100{ }^{\circ} \mathrm{C}$ in toluene with more than $80 \%$ conversion reached after $9 \mathrm{~h}$ (Table 4, entries 3 and 10). Kinetic studies show the first-order dependency on s-lactide concentration, supported by linear plots of $\ln \left([\mathrm{L}-\mathrm{LA}]_{0} /[\mathrm{L}-\mathrm{LA}]_{t}\right)$ $v s$. time of polymerisation (Fig. S85 and S100†) with $k_{\text {obs }}$ values of 0.24 and $0.19 \mathrm{~h}^{-1}$ for the polymerisation with 9 and $\mathbf{1 0}$, respectively. Isotactic poly(L-lactide) was produced with an absence of epimerisation occurring during polymerisation as evidenced by a singlet in the methine region of the homonuclear decoupled ${ }^{1} \mathrm{H}\left\{{ }^{1} \mathrm{H}\right\}$ NMR spectrum (Fig. S42 and S50†). Polymerisation of L-lactide using $\mathbf{9}$ were also carried out at 70, 80 and $90{ }^{\circ} \mathrm{C}$ with $[\mathrm{L}-\mathrm{LA}]_{0}:[\mathrm{Al}]_{0}=100: 1$ (Table 4 and Fig. 9). The enthalpy of activation $\left(\Delta H^{\ddagger}\right)$ of $71 \mathrm{~kJ} \mathrm{~mol}^{-1}$ and entropy of activation $\left(\Delta S^{\ddagger}\right)$ of $-69 \mathrm{~J} \mathrm{~mol}^{-1} \mathrm{~K}^{-1}$ were calculated from an Eyring plot of $\ln \left(k_{\text {obs }} / T\right) v s$. 1/T (Fig. S90†). Rate of L-lactide polymerisation using 9 at $70{ }^{\circ} \mathrm{C}$ is comparable to those using hemi-salen aluminium alkyl complexes with ${ }^{i} \mathrm{PrOH}\left(k_{\mathrm{obs}}=\right.$ 0.04-0.06 $\mathrm{h}^{-1}$ ) under the same conditions reported by Pang et al..$^{28}$

The polymerisation of rac-lactide using 9 at $100{ }^{\circ} \mathrm{C}$ shows the first-order dependence on rac-lactide concentration (Fig. S99†) with a similar rate to L-lactide $\left(k_{\mathrm{obs}}=0.30\right.$ and $0.24 \mathrm{~h}^{-1}$ for $r a c$ - and L-lactide, respectively). The polymer tacticity studied by ${ }^{1} \mathrm{H}\left\{{ }^{1} \mathrm{H}\right\}$ NMR spectroscopy showed slight heterotactic polylactide with $P_{\mathrm{r}}$ values of $0.53-0.57$ (Fig. S48 and S49†), suggesting chain-end controlled rac-lactide polymerisation using 9 where the stereocentre in the last unit on the propagating chain favours the racemic-enchainment. Although isoselectivity in rac-lactide polymerisation has been generally obtained from using aluminium catalysts, ${ }^{29}$ some known aluminium complexes were reported to produce heterotactic polylactides. ${ }^{29 i, 30}$ Gibson et al. prepared aluminium methyl complex supported by tetradentate phenoxy-amine ligand. ${ }^{30 b}$ Heterotactic polylactide $\left(P_{\mathrm{r}}=0.57\right)$ was produced after $280 \mathrm{~h}$ with $[\mathrm{rac}-\mathrm{LA}]_{0}:[\mathrm{Al}]_{0}=50$ in toluene at $70{ }^{\circ} \mathrm{C}$. Aluminium methyl complexes supported by asymmetric [ONNO']-type Salan ligand reported by Hormnirun et al. polymerised 100 equivalents of rac-LA with benzyl alcohol in toluene at $70{ }^{\circ} \mathrm{C}$ (more than $80 \%$ conversion after $300 \mathrm{~h}$ ). ${ }^{30 e}$ Heterotactic polylactides were formed with $P_{\mathrm{r}}$ values of 0.64-0.74.

All polymerisations produced polymers with monomodal molecular weight distribution and moderate $M_{\mathrm{w}} / M_{\mathrm{n}}$ values (1.29-1.44, Table 4). Experimental $M_{\mathrm{n}}$ values are also consistent with those calculated for one chain per metal centre, suggesting a well-controlled and living manner of polymerisation can be attained under harsh experimental conditions

Table 4 Selected polymerisation data using complexes 9 and $10^{a}$

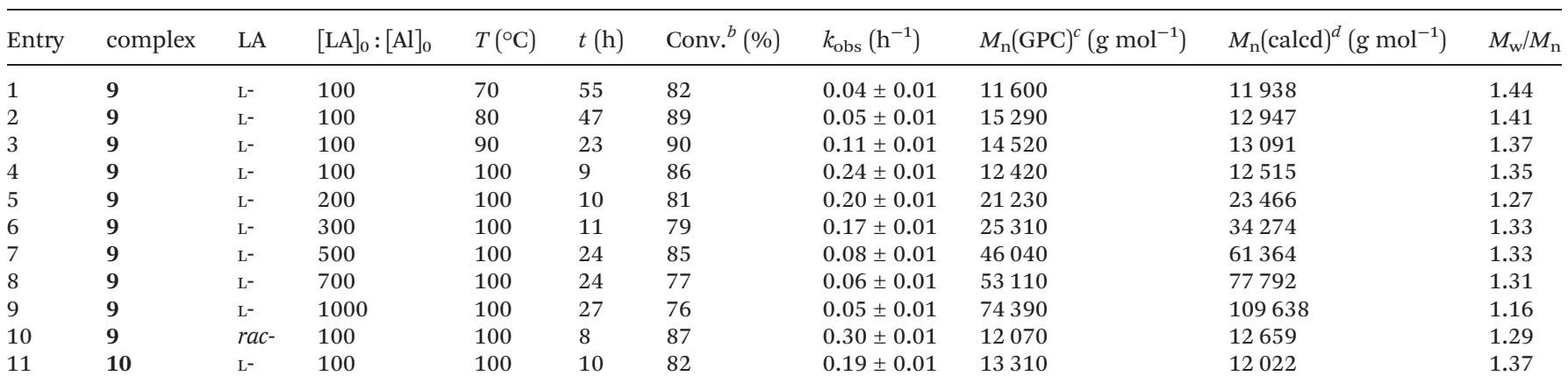

${ }^{a}$ Conditions: $[\mathrm{LA}]_{0}=0.5 \mathrm{M}, 4.0 \mathrm{~mL}$ toluene. ${ }^{b}$ Measured by ${ }^{1} \mathrm{H}$ NMR spectroscopic analyses. ${ }^{c}$ Determined by GPC in THF against PS standards using the appropriate Mark-Houwink corrections. ${ }^{22}{ }^{d}$ Calculated $M_{\mathrm{n}}$ for PLA synthesised by using $9=$ conv. $(\%) \times 100 \times 144.1+122.2$ and calculated $M_{\mathrm{n}}$ for PLA synthesised by using $\mathbf{1 0}=$ conv. $(\%) \times 100 \times 144.1+206.2$. 


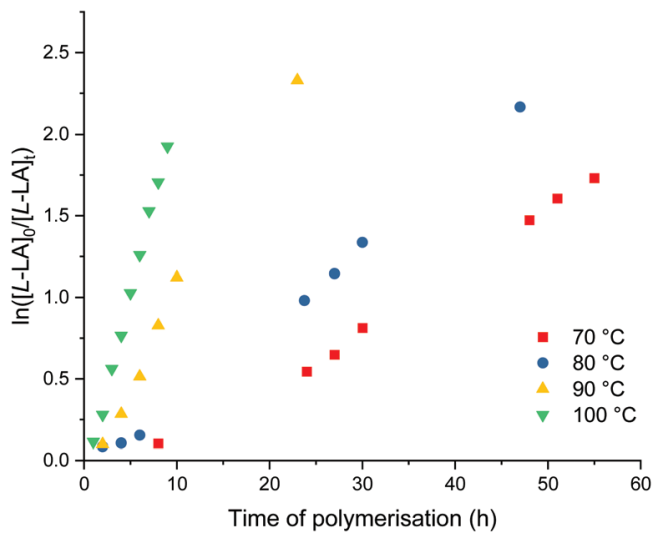

Fig. 9 Plots of $\ln \left([L-L A]_{0} /[L-L A]_{t}\right)$ vs. time of polymerisation. ROP of L-lactide using $9.70{ }^{\circ} \mathrm{C}$, Red square: $k_{\text {obs }}=0.03 \pm 0.01 \mathrm{~h}^{-1}, R^{2}=0.993$. $80{ }^{\circ} \mathrm{C}$, Blue circle: $k_{\text {obs }}=0.04 \pm 0.01 \mathrm{~h}^{-1}, R^{2}=0.993 .90^{\circ} \mathrm{C}$, Yellow triangle: $k_{\mathrm{obs}}=0.11 \pm 0.01 \mathrm{~h}^{-1}, R^{2}=0.989 .100{ }^{\circ} \mathrm{C}$, green down triangle: $k_{\text {obs }}=0.24 \pm 0.01 \mathrm{~h}^{-1}, R^{2}=0.995$. Conditions: $[\mathrm{L}-\mathrm{LA}]_{0}=0.5 \mathrm{M}$, $[\mathrm{L}-\mathrm{LA}]_{0}:[9]_{0}=100: 1,4.0 \mathrm{~mL}$ toluene.

including high temperature and long polymerisation time. The polymerisation of L-lactide with 9 using various monomer to catalyst ratios was carried out at $100{ }^{\circ} \mathrm{C}$ in toluene to determine the kinetic order dependence on catalyst concentrations. The concentration of L-lactide remains at $0.5 \mathrm{M}$, while the concentration of $\mathbf{9}$ was varied, providing the ratio of $[\mathrm{L}-\mathrm{LA}]_{0}:[\mathbf{9}]_{0}=$ 200, 300, 500, 700 and 1000. The polymerisation data are summarised in Table 4 (entries 5-9). Plots of first-order dependence on L-lactide concentration are shown in Fig. 10. The gradient of 0.79 from the plot of $-\ln \left(k_{\text {obs }}\right) v s .-\ln [9]_{0}$ is indicative of the first-order dependence on catalyst concentration (Fig. S97†).

The propagation rate constant $\left(k_{\mathrm{p}}\right)$ of $70 \pm 11 \mathrm{M}^{-1} \mathrm{~h}^{-1}$ was calculated from the plot between $k_{\text {obs }} v s$. $[9]_{0}$ (Fig. S98†). The

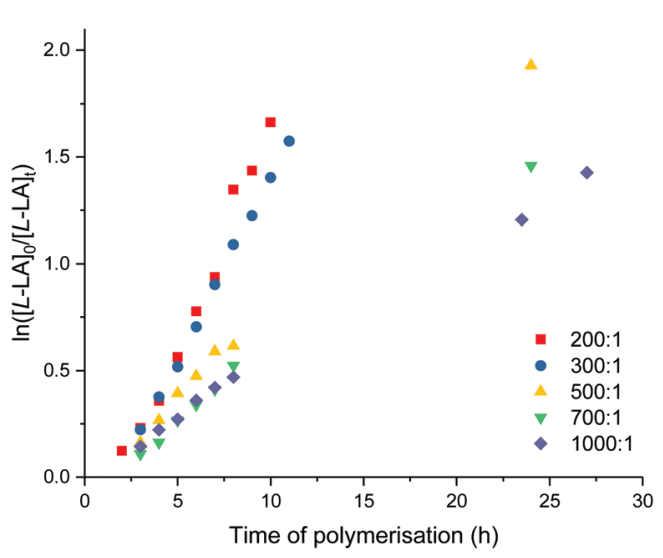

Fig. 10 Plots of $\ln \left([L-L A]_{0} /[L-L A]_{t}\right)$ vs. time of polymerisation. ROP of L-lactide using 9. $[\mathrm{L}-\mathrm{LA}]_{0} /[]_{0}=200$, red square: $k_{\mathrm{obs}}=0.20 \pm 0.01 \mathrm{~h}^{-1}$, $R^{2}=0.980$. [L-LA $]_{0} /[9]_{0}=300$, blue circle: $k_{\text {obs }}=0.17 \pm 0.01 \mathrm{~h}^{-1}, R^{2}=$ 0.998. $[\mathrm{L}-\mathrm{LA}]_{\mathrm{O}} /[9]_{0}=500$, yellow triangle: $k_{\mathrm{obs}}=0.08 \pm 0.01 \mathrm{~h}^{-1}, R^{2}=$ 0.997. $[\mathrm{L}-\mathrm{LA}]_{0} /[9]_{0}=700$, green down triangle: $k_{\text {obs }}=0.06 \pm 0.01 \mathrm{~h}^{-1}$, $R^{2}=0.993$. $[\mathrm{L}-\mathrm{LA}]_{0} /[9]_{0}=1000$, purple diamond: $k_{\mathrm{obs}}=0.05 \pm 0.01 \mathrm{~h}^{-1}$, $R^{2}=0.996$. Conditions: $[\mathrm{L}-\mathrm{LA}]_{0}=0.5 \mathrm{M}, 4.0 \mathrm{~mL}$ toluene at $100^{\circ} \mathrm{C}$. overall rate law was determined as $-\mathrm{d}[\mathrm{L}-\mathrm{LA}] / \mathrm{d} t=k_{\mathrm{p}}[\mathrm{L}-\mathrm{LA}][\mathbf{9}]$. At a $[\mathrm{L}-\mathrm{LA}]_{0}:[\mathrm{Al}]_{0}$ ratio of 200 and $300, M_{\mathrm{n}}(\mathrm{GPC})$ values are similar to those calculated. However, polylactide obtained from high monomer loading $\left([\mathrm{L}-\mathrm{LA}]_{0}:[\mathrm{Al}]_{0}=500,700\right.$ and 1000) show molecular weights lower than those predicted with moderate $M_{\mathrm{w}} / M_{\mathrm{n}}$ values (1.16-1.33). The MALDI-ToF mass spectrum of polymer synthesised by 9 (Fig. S60†) shows peaks corresponding to polylactide with $\mathrm{O}-2,6-\mathrm{Me}-\mathrm{C}_{6} \mathrm{H}_{3}$ and $\mathrm{OH}$ endgroups. Other peaks are assigned to polylactide terminated with ${ }^{t \mathrm{Bu}} \mathrm{NH}$ and $\mathrm{OH}$ end-groups. Double-site initiator from the amido and aryloxide ligands, which was previously observed from ROP initiated by 4 , results in the mismatch between the $M_{\mathrm{n}}(\mathrm{GPC})$ values and those calculated for one polymer chain per metal centre.

\section{Conclusions}

A series of new scandium (1-7) and aluminium (8-10) constrained geometry permethylindenyl complexes were reported. Scandium complexes (1-5 and 7) are highly active catalysts for lactide polymerisation whereas aluminium complexes (8-10) show moderate activity. First-order dependence on lactide concentration was observed in all polymerisations. First-order dependence on catalyst concentration was measured from polymerisation of L-lactide using 4 and 9 with $k_{\mathrm{p}}$ values of $1120 \pm 29$ and $70 \pm 11 \mathrm{M}^{-1} \mathrm{~h}^{-1}$, respectively. Polymers with $M_{\mathrm{n}}$ (GPC) values lower than those calculated for one polymer chain per metal centre were observed, attributed to the doublesite nature of scandium and aluminium complexes using these amido and aryloxide ligands.

Complexes with a more electron donating substituent on the amido ligand $\left({ }^{i} \mathrm{Pr}>{ }^{n} \mathrm{Bu}>\mathrm{Ph}\right)$ show greater polymerisation activity as observed from L-lactide polymerisation using 1-3 with one equivalent of benzyl alcohol and L-and rac-lactide polymerisation using 4, 5 and 7. The effect of the less sterically demanding aryloxide substituent was observed with the scandium system as $5\left(\mathrm{O}-2,4-{ }^{t} \mathrm{Bu}^{-} \mathrm{C}_{6} \mathrm{H}_{3}\right)$ shows higher activity than $4\left(\mathrm{O}-2,6-{ }^{i} \mathrm{Pr}^{-} \mathrm{C}_{6} \mathrm{H}_{3}\right)$. Complexes 1-5 and 7-10 produced isotactic poly(L-lactide) without epimerisation occurring during polymerisation. Moderate heterotactically enriched polylactide $\left(P_{\mathrm{r}}=0.53-0.68\right)$ was obtained from polymerisation of raclactide using 4, 5, 7 and 9, suggesting minor influence of the metal centre, the amido substituent and the aryloxide group on the stereoselectivity.

\section{Experimental section}

\section{General polymerisation procedure}

To a stock solution of 1-3 and 8 (31.25 $\mu \mathrm{mol})$ in toluene (5.00 $\mathrm{mL})$, benzyl alcohol $(31.25 \mu \mathrm{mol})$ was added. L-Lactide $(2.50 \mathrm{mmol})$ was added into an ampoule and dissolved in $4.0 \mathrm{~mL}$ of toluene. The catalyst stock solution $(1.0 \mathrm{~mL})$ was added to the solution of lactide in the ampoule, corresponding to an initial lactide concentration of $0.5 \mathrm{M}$ and $\mathrm{a}$ 
$[\mathrm{L}-\mathrm{LA}]_{0}:[\mathrm{Sc}]_{0}:[\mathrm{BnOH}]_{0}$ ratio of $400: 1: 1$. The polymerisation ampoule was then stirred at in the preheated oil bath at desired temperature.

A stock solution of 4, 5, 7, 9, $10(17.50 \mu \mathrm{mol})$ in benzene $(2.50 \mathrm{~mL})$ was prepared. The stock solution of catalyst $(3.50 \mu \mathrm{mol}, 0.50 \mathrm{~mL})$ was added into a toluene solution of lactide $(0.50 \mathrm{~g}, 3.50 \mathrm{mmol}, 6.50 \mathrm{~mL})$ in the ampoule, corresponding to an initial lactide concentration of $0.5 \mathrm{M}$ and a monomer-to-catalyst ratio of $1000: 1$. The polymerisation ampoule was then stirred at in the preheated oil bath at desired temperature.

Aliquots (ca. $0.1 \mathrm{~mL})$ were taken at appropriate time intervals and quenched with THF ( $c a .0 .3 \mathrm{~mL}$ ). The volatiles were evaporated to give PLA. The monomer to polymer\% conversion was determined using ${ }^{1} \mathrm{H}$ NMR spectroscopy and measured by integration of the CHMe resonances of the unreacted monomer and PLA. After the chosen time, the reaction was quenched with THF. The polymer was isolated by addition of pentane to a concentrated solution of PLA to yield a precipitate which was washed with pentane and dried under vacuum at $30{ }^{\circ} \mathrm{C}$.

\section{Conflicts of interest}

There are no conflicts to declare.

\section{Acknowledgements}

N. D., J.-C. B. and Z. R. T. would like to thank SCG Chemicals Co., Ltd (Thailand) for financial support and for a SCG Research Fellowship (Z. R. T.). Chemical Crystallography (University of Oxford) is thanked for the use of the diffractometers.

\section{Notes and references}

1 (a) R. H. Platel, L. M. Hodgson and C. K. Williams, Polym. Rev., 2008, 48, 11-63; (b) X. Zhang, M. Fevre, G. O. Jones and R. M. Waymouth, Chem. Rev., 2018, 118, 839-885.

2 (a) B. J. O'Keefe, M. A. Hillmyer and W. B. Tolman, J. Chem. Soc., Dalton Trans., 2001, 2215-2224; (b) O. Dechy-Cabaret, B. Martin-Vaca and D. Bourissou, Chem. Rev., 2004, 104, 6147-6176; (c) J. Wu, T.-L. Yu, C.-T. Chen and C.-C. Lin, Coord. Chem. Rev., 2006, 250, 602-626; (d) P. J. Dijkstra, H. Du and J. Feijen, Polym. Chem., 2011, 2, 520-527.

3 (a) W. E. Piers, P. J. Shapiro, E. E. Bunel and J. E. Bercaw, Synlett, 1990, 1990, 74-84; (b) P. J. Shapiro, E. Bunel, W. P. Schaefer and J. E. Bercaw, Organometallics, 1990, 9, 867-869; (c) P. J. Shapiro, W. P. Schaefer, J. A. Labinger, J. E. Bercaw and W. D. Cotter, J. Am. Chem. Soc., 1994, 116, 4623-4640.

4 J. Okuda, Chem. Ber., 1990, 123, 1649-1651.

5 (a) J. Okuda, Dalton Trans., 2003, 2367-2378; (b) J. Cano and K. Kunz, J. Organomet. Chem., 2007, 692, 4411-4423; (c) H. Braunschweig and F. M. Breitling, Coord. Chem. Rev., 2006, 250, 2691-2720.

6 (a) Y.-X. Chen, P.-F. Fu, C. L. Stern and T. J. Marks, Organometallics, 1997, 16, 5958-5963; (b) Y.-X. Chen and T. J. Marks, Organometallics, 1997, 16, 3649-3657; (c) A. L. McKnight, M. A. Masood, R. M. Waymouth and D. A. Straus, Organometallics, 1997, 16, 2879-2885; (d) M. Kamigaito, T. K. Lal and R. M. Waymouth, J. Polym. Sci., Part A: Polym. Chem., 2000, 38, 4649-4660; (e) E. Y. X. Chen, W. J. Kruper, G. Roof and D. R. Wilson, J. Am. Chem. Soc., 2001, 123, 745-746; $(f)$ J. M. Santos, M. R. Ribeiro, M. F. Portela, H. Cramail, A. Deffieux, A. Antiñolo, A. Otero and S. Prashar, Macromol. Chem. Phys., 2002, 203, 139-145; (g) Y. Zhang, Y. Mu, C. Lü, G. Li, J. Xu, Y. Zhang, D. Zhu and S. Feng, Organometallics, 2004, 23, 540-546; (h) H. Wang, H.-S. Chan, J. Okuda and Z. Xie, Organometallics, 2005, 24, 3118-3124; (i) J. Li, W. Gao, Q. Wu, H. Li and Y. Mu, J. Organomet. Chem., 2011, 696, 2499-2506.

7 D. W. Carpenetti, L. Kloppenburg, J. T. Kupec and J. L. Petersen, Organometallics, 1996, 15, 1572-1581.

8 (a) D. B. Millward, A. P. Cole and R. M. Waymouth, Organometallics, 2000, 19, 1870-1878; (b) P.-J. Sinnema, L. van der Veen, A. L. Spek, N. Veldman and J. H. Teuben, Organometallics, 1997, 16, 4245-4247.

9 (a) F. Amor and J. Okuda, J. Organomet. Chem., 1996, 520, 245-248; (b) J. Klosin, W. J. Kruper, P. N. Nickias, G. R. Roof, P. De Waele and K. A. Abboud, Organometallics, 2001, 20, 2663-2665; (c) L. Li, M. V. Metz, H. Li, M.-C. Chen, T. J. Marks, L. Liable-Sands and A. L. Rheingold, J. Am. Chem. Soc., 2002, 124, 12725-12741; (d) S. K. Noh, J. Lee and D.-h. Lee, J. Organomet. Chem., 2003, 667, 53-60; (e) S. K. Noh, M. Lee, D. H. Kum, K. Kim, W. S. Lyoo and D.-H. Lee, J. Polym. Sci., Part A: Polym. Chem., 2004, 42, 1712-1723; (f) J. Wang, H. Li, N. Guo, L. Li, C. L. Stern and T. J. Marks, Organometallics, 2004, 23, 5112-5114.

10 (a) M. E. Rerek and F. Basolo, J. Am. Chem. Soc., 1984, 106, 5908-5912; (b) J. M. O'Connor and C. P. Casey, Chem. Rev., 1987, 87, 307-318; (c) M. J. Calhorda, C. C. Romão and L. F. Veiros, Chem. - Eur. J., 2002, 8, 868875.

11 T. K. Miyamoto, M. Tsutsui and L.-B. Chen, Chem. Lett., 1981, 10, 729-730.

12 (a) T. J. Williams, J.-C. Buffet, Z. R. Turner and D. O'Hare, Catal. Sci. Technol., 2018, 8, 5454-5461; (b) T. J. Williams, A. D. H. Smith, J.-C. Buffet, Z. R. Turner and D. O'Hare, Mol. Catal., 2020, 486, 110872.

13 (a) J. V. Lamb, J.-C. Buffet, Z. R. Turner and D. O'Hare, Polym. Chem., 2019, 10, 1386-1398; (b) J. V. Lamb, J.-C. Buffet, J. E. Matley, C. M. R. Wright, Z. R. Turner and D. O'Hare, Dalton Trans., 2019, 48, 2510-2520; (c) J. V. Lamb, J. C. Abell, J. E. McLaren, J.-C. Buffet, Z. R. Turner and D. O'Hare, Mol. Catal., 2020, 484, 110735; (d) J. V. Lamb, J.-C. Buffet, Z. R. Turner and D. O'Hare, Macromolecules, 2020, 53, 929-935. 
14 N. Diteepeng, J.-C. Buffet, Z. R. Turner and D. O'Hare, Dalton Trans., 2019, 48, 16099-16107.

15 A. W. Addison, T. N. Rao, J. Reedijk, J. van Rijn and G. C. Verschoor, J. Chem. Soc., Dalton Trans., 1984, 13491356.

16 (a) J. L. Atwood and K. D. Smith, J. Chem. Soc., Dalton Trans., 1973, 2487-2490; (b) N. C. Burton, F. G. N. Cloke, P. B. Hitchcock, H. C. de Lemos and A. A. Sameh, J. Chem. Soc., Chem. Commun., 1989, 1462-1464; (c) B. D. Ward, S. R. Dubberley, A. Maisse-François, L. H. Gade and P. Mountford, J. Chem. Soc., Dalton Trans., 2002, 46494657; (d) K. A. Tupper and T. D. Tilley, J. Organomet. Chem., 2005, 690, 1689-1698; (e) B. Wang, M. Nishiura, J. Cheng and Z. Hou, Dalton Trans., 2014, 43, 14215-14218; (f) A. Fridrichová, A. Růžička, M. Lamač and M. Horáček, Inorg. Chem. Commun., 2017, 76, 62-66; (g) Z. Zhou, J. Greenough, Z. Wei and M. A. Petrukhina, Acta Crystallogr., Sect. C: Struct. Chem., 2017, 73, 420-423.

17 L. Yang, D. R. Powell and R. P. Houser, Dalton Trans., 2007, 955-964.

18 (a) P. Jutzi, J. Dahlhaus, B. Neumann and H.-G. Stammler, Organometallics, 1996, 15, 747-752; (b) J. M. Pietryga, J. D. Gorden, C. L. B. Macdonald, A. Voigt, R. J. Wiacek and A. H. Cowley, J. Am. Chem. Soc., 2001, 123, 7713-7714; (c) M. Weger, P. Pahl, F. Schmidt, B. S. Soller, P. J. Altmann, A. Pöthig, G. Gemmecker, W. Eisenreich and B. Rieger, Macromolecules, 2019, 52, 7073-7080.

19 R. J. Wiacek, C. L. B. Macdonald, J. N. Jones, J. M. Pietryga and A. H. Cowley, Chem. Commun., 2003, 430-431.

20 (a) M. Mazzeo, M. Lamberti, I. D’Auria, S. Milione, J. C. Peters and C. Pellecchia, J. Polym. Sci., Part A: Polym. Chem., 2010, 48, 1374-1382; (b) V. Rad'Kov, T. Roisnel, A. Trifonov, J. F. Carpentier and E. Kirillov, Eur. J. Inorg. Chem., 2014, 4168-4178; (c) J. El Haj Hassan, V. Radkov, V. Dorcet, J. F. Carpentier and E. Kirillov, J. Organomet. Chem., 2016, 823, 34-39; (d) H. Xie, C. Wu, D. Cui and Y. Wang, J. Organomet. Chem., 2018, 875, 5-10.

21 (a) H. Ma, T. P. Spaniol and J. Okuda, Angew. Chem., Int. Ed., 2006, 45, 7818-7821; (b) M. Mazzeo, R. Tramontano, M. Lamberti, A. Pilone, S. Milione and C. Pellecchia, Dalton Trans., 2013, 42, 9338-9351; (c) Y. Chapurina, J. Klitzke, O. d. L. Casagrande Jr., M. Awada, V. Dorcet, E. Kirillov and J.-F. Carpentier, Dalton Trans., 2014, 43, 14322-14333.

22 J. R. Dorgan, J. Janzen, D. M. Knauss, S. B. Hait, B. R. Limoges and M. H. Hutchinson, J. Polym. Sci., Part B: Polym. Phys., 2005, 43, 3100-3111.

23 C. Bakewell, A. J. P. White, N. J. Long and C. K. Williams, Angew. Chem., Int. Ed., 2014, 53, 9226-9230.

24 (a) Y. Ning, Y. Zhang, A. Rodriguez-Delgado and E. Y. X. Chen, Organometallics, 2008, 27, 5632-5640; (b) J.-C. Buffet, G. R. Harris, J. J. Coward, T. A. Q. Arnold, Z. R. Turner and D. O'Hare, J. Organomet. Chem., 2016, 801, 87-95; (c) K. Beckerle, K. C. Hultzsch and J. Okuda, Macromol. Chem. Phys., 1999, 200, 1702-1707.

25 Y. Cui, W. Gu, Y. Wang, B. Zhao, Y. Yao and Q. Shen, Catal. Sci. Technol., 2015, 5, 3302-3312.

26 C. Bakewell, A. J. P. White, N. J. Long and C. K. Williams, Inorg. Chem., 2015, 54, 2204-2212.

27 (a) M. H. Chisholm and E. E. Delbridge, New J. Chem., 2003, 27, 1167-1176; (b) A. F. Douglas, B. O. Patrick and P. Mehrkhodavandi, Angew. Chem., Int. Ed., 2008, 47, 22902293; (c) I. Peckermann, A. Kapelski, T. P. Spaniol and J. Okuda, Inorg. Chem., 2009, 48, 5526-5534; (d) J. Börner, I. dos Santos Vieira, A. Pawlis, A. Döring, D. Kuckling and S. Herres-Pawlis, Chem. - Eur. J., 2011, 17, 4507-4512; (e) H. Sun, J. S. Ritch and P. G. Hayes, Dalton Trans., 2012, 41, 3701-3713; (f) S. Abbina and G. Du, ACS Macro Lett., 2014, 3, 689-692.

28 B. Gao, R. Duan, X. Pang, X. Li, Z. Qu, Z. Tang, X. Zhuang and X. Chen, Organometallics, 2013, 32, 54355444.

29 (a) N. Spassky, M. Wisniewski, C. Pluta and A. Le Borgne, Macromol. Chem. Phys., 1996, 197, 2627-2637; (b) M. Wisniewski, A. L. Borgne and N. Spassky, Macromol. Chem. Phys., 1997, 198, 1227-1238; (c) T. M. Ovitt and G. W. Coates, J. Polym. Sci., Part A: Polym. Chem., 2000, 38, 4686-4692; (d) C. P. Radano, G. L. Baker and M. R. Smith, J. Am. Chem. Soc., 2000, 122, 1552-1553; (e) Z. Zhong, P. J. Dijkstra and J. Feijen, Angew. Chem., Int. Ed., 2002, 41, 4510-4513; $(f)$ N. Nomura, R. Ishii, M. Akakura and K. Aoi, J. Am. Chem. Soc., 2002, 124, 5938-5939; (g) T. M. Ovitt and G. W. Coates, J. Am. Chem. Soc., 2002, 124, 1316-1326; (h) Z. Zhong, P. J. Dijkstra and J. Feijen, J. Am. Chem. Soc., 2003, 125, 11291-11298; (i) P. Hormnirun, E. L. Marshall, V. C. Gibson, A. J. P. White and D. J. Williams, J. Am. Chem. Soc., 2004, 126, 2688-2689; ( $j$ ) M. Bouyahyi, T. Roisnel and J.-F. Carpentier, Organometallics, 2010, 29, 491-500.

30 (a) H. Ma, G. Melillo, L. Oliva, T. P. Spaniol, U. Englert and J. Okuda, Dalton Trans., 2005, 721-727; (b) Z. Tang and V. C. Gibson, Eur. Polym. J., 2007, 43, 150-155; (c) F. Hild, P. Haquette, L. Brelot and S. Dagorne, Dalton Trans., 2010, 39, 533-540; (d) E. L. Whitelaw, G. Loraine, M. F. Mahon and M. D. Jones, Dalton Trans., 2011, 40, 11469-11473; (e) P. Sumrit and P. Hormnirun, Macromol. Chem. Phys., 2013, 214, 1845-1851; $(f)$ E. D. Cross, L. E. N. Allan, A. Decken and M. P. Shaver, J. Polym. Sci., Part A: Polym. Chem., 2013, 51, 1137-1146; (g) K. Press, I. Goldberg and M. Kol, Angew. Chem., 2015, 127, 15071-15074; (h) S. Gesslbauer, R. Savela, Y. Chen, A. J. P. White and C. Romain, ACS Catal., 2019, 9, 7912-7920. 